\title{
More than a Lifeline: Low-Income Households' Telecommunications Preferences
}

\author{
Dr. Janice A. Hauge \\ Dr. Eric P. Chiang \\ Dr. Mark A. Jamison* \\ Public Utility Research Center \\ University of Florida
}

April 4, 2008

For information or to provide comments on this report, please contact Dr. Mark A. Jamison, Director, PURC, University of Florida, PO Box 117142, Gainesville, FL 32611-7142, +1.352-392-6148, jamisoma@,ufl.edu.

\footnotetext{
* The authors are Assistant Professor, Department of Economics, University of North Texas; Associate Professor, Department of Economics, Florida Atlantic University; and Director, Public Utility Research Center (PURC), University of Florida, respectively.
} 


\section{Acknowledgements}

We would like to thank James Sichter and John Horrigan for their comments on this research, the managers and staff at the University of Florida's Bureau of Business and Economic Research for the advice on the surveys and for conducting the surveys, and Patricia Casey for her editorial work. Finally, we would like to thank AT\&T and Embarq for funding this research; the Florida Public Service Commission staff for its support; the Office of Public Counsel for its input on this research; and Ava Parker for her advice and for her efforts in making Lifeline successful in Florida. The authors are solely responsible for all content, errors, and omissions. 


\section{Executive Summary}

Florida's Lifeline program is part of a nationwide program to increase the availability of telecommunications services to low-income households by providing a credit to monthly recurring charges for local telephone service. In Florida, households can receive up to a $\$ 13.50$ discount on their monthly local phone bills. The Federal Communications Commission (FCC) established the Lifeline program in the belief that low-income households find landline local telephone service to be essential for their social and economic livelihoods, and that a discount on the price for landline telephone service was needed to make the service affordable. There is mounting evidence that these assumptions do not hold true today. In 2005, about 90 percent of low-income households in Florida subscribed to landline telephone service even though only about 13 percent of the households eligible for Lifeline took the discount. Furthermore, about half of the low-income households were purchasing cellular phone service.

We undertake this study to better understand low-income households' choices with respect to communications services and participation in Lifeline. Specifically, the research is designed to address four fundamental questions, namely:

- How do enrollment procedures impact households' participation in Lifeline?

- What do eligible households understand from the enrollment efforts?

- How does low-income household use of wireless communications impact enrollment in Lifeline?

- What communications services are low-income households and consumers in Florida purchasing and/or using?

We employ surveys and statistical analyses to study Floridians' participation in Lifeline and their choices for communications services. The University of Florida's Bureau of Economic 
and Business Research (BEBR) conducted the surveys and used three approaches: a survey of customers responding via landline phone, a survey of customers responding via cellular phone, and an intercept survey (i.e., an in-person interview) of individuals exiting two different Department of Children and Family (DCF) offices in Florida.

Comparing demographic statistics between phone surveys and intercept surveys, intercept survey respondents were more likely to be women, to be younger on average, to rent their residence, and to have larger household size and more children. In addition, some demographic variables differed between the landline and cellular survey. In particular, the average age of respondents to the cellular survey was lower than the average age of respondents to the landline survey, perhaps indicating that younger people preferred cellular over landline for voice communications. Landline respondents also tended to be older than the intercept survey respondents. The respondents in the intercept survey had statistically significant lower incomes than the respondents in the other two surveys, as would be expected because the phone surveys sample a cross section of Floridians with phones, while the intercept survey samples only Floridians who visited DCF offices. In general, the phone surveys by and large captured higher income households than did the intercept survey, while the intercept and cellular surveys captured younger people than did the landline survey.

We find that cellular phones are becoming more popular and reportedly more essential than landline phones. For example, 56.3 percent of cellular survey respondents subscribed to a landline phone, but 83.2 percent of landline survey respondents subscribed to a cellular phone. Seventy-six percent of intercept survey respondents subscribed to a cellular phone. Analyzing the number of persons with either only a landline phone or only a cellular phone, we find a growing trend that those who subscribe only to one form of communication (landline or cellular 
phone) are increasingly choosing a cellular phone. This holds for low-income households as well as on average: respondents who are presumed eligible for Lifeline are more likely to use only cellular phones than respondents presumed not eligible for Lifeline. ${ }^{1}$ We also find a significant shift towards cellular telephone usage among low-income households, which could imply that landline phones are now becoming a luxury good.

In addition to usage patterns, we also study the value that consumers place on modes of communications. For the landline survey respondents, we find that those presumed eligible for Lifeline on averaged valued their landline telephone service nearly 60 percent more than presumed non-eligible respondents. For cellular survey respondents, this difference was over 50 percent. Such a difference might have resulted from higher proportions of presumed eligible customers having had only one type of phone, which would have made this phone more valuable to them than to customers who had both landline and cellular phones. Also, presumed eligible respondents were more price sensitive, as indicated by the higher percentages of respondents who report that they would cancel their landline service or cellular service should their monthly bills rise. Such price sensitivity probably reflects these respondents' lower income levels relative to the presumed non-eligible respondents.

With respect to cellular phone usage, we find that the penetration of prepaid cellular phones had about doubled for low-income households in the past three years. Indeed our data show that low-income households (those who are presumed eligible for the Lifeline program) were more likely to use prepaid cellular calling plans than presumed non-eligible households. This preference suggests that Lifeline discounts might be more beneficial to low-income households if applied to prepaid cellular phones than to landline or postpaid cellular phones. The

\footnotetext{
${ }^{1}$ We do not measure precisely whether survey respondents qualify for Lifeline; rather, we estimate eligibility based on reported income and household sizes.
} 
ability to control phone costs was the primary motivation for using prepaid cellular, especially for respondents in the intercept survey in which there was a higher proportion of low-income households than in the other surveys.

We also find that presumed eligible respondents reportedly were more willing to pay for a landline phone than were presumed non-eligible respondents. Furthermore, presumed eligible respondents were more likely not to have a landline phone due to a recent move, perhaps suggesting that lower-income households relocated more frequently than higher-income households. A possible implication for Lifeline policy is that a cellular phone might be more suitable for many low-income households than a landline phone.

Regarding Lifeline participation, we find that among respondents presumed eligible for Lifeline, only 10.2 percent of landline survey respondents, 4.1 percent of cellular survey respondents, and 19.9 percent of intercept survey respondents subscribed to Lifeline, a lower subscription rate than found in earlier studies. This may be influenced by changing communications consumption patterns among low-income households, but awareness of the Lifeline program remains an important factor: in each of the phone surveys less than one-fourth of the respondents were aware of Lifeline. Surprisingly, only 50.3 percent of Lifeline eligible respondents leaving DCF offices were aware of the program. Among the respondents who were aware of the program, the subscription rate for respondents to the landline, cellular, and intercept surveys was significantly higher at 50.0 percent, 17.4 percent, and 39.8 percent, respectively.

\section{Summary of Key Findings and Recommendations}

Our key findings and recommendations include the following: 
First, we suggest decreasing the emphasis on landline service and increasing the opportunities for eligible households to obtain discounts on prepaid cellular phones. Cellular phones, in particular prepaid cellular phones, are becoming the communications mode of choice for low-income households. As was found in the initial PURC studies, ${ }^{2}$ the focus on landline phones could be an impediment to low-income households' adoption of more advanced telecommunications technologies.

Second, we believe that consideration should be given to whether price discounts are an important feature for Lifeline. Prices do not appear to be a primary barrier to low-income households' use of telecommunications services. Frequency of moving for low-income households appears to be one of the major impediments to having a phone. An emphasis on helping low-income households obtain cellular phones might be more effective than price discounts, especially price discounts on landline phones.

Third, to the extent that price discounts remain a feature of outreach to low-income households, we believe a program design that does not favor one technology over another could become appropriate as technologies change. For example, a program that provides a technologyneutral communications stamp could allow low-income households to easily migrate to Voiceover-Internet Protocol (VoIP), broadband, or other new technologies.

Finally, we suggest that participation procedures should be further simplified if Lifelinelike programs are to continue. The processes for learning about Lifeline, determining eligibility, and signing up remain a hindrance. In lieu of less-targeted marketing approaches, perhaps outreach events and DCF offices could distribute cards for prepaid wireless phones or could provide prepaid phones at a discount. Perhaps Lifeline wireless prepaid minutes could be sold at

\footnotetext{
${ }^{2}$ See Holt and Jamison (2006, 2007), Hauge and Jamison (Forthcoming), Hauge et al. (2007), Hauge et al. (Forthcoming), Brown and Jamison (2005), Brown (2006a, 2006b, 2006c), and Williamson (2006).
} 
common retail outlets such as WalMart, where a person could qualify to purchase such minutes in the same way he or she currently uses food stamps or prescription drug discounts. 


\section{List of Tables}

TABLE

PAGE NUMBER

Table 1 Comparison of Demographic Statistics among the State of Florida, Duval County, and Miami-Dade County, 2003 and 2006

Table 2 Sample Means for Each Demographic Indicator by Survey Method, 2008

Table 3 Number of Respondents by Age Group for Each Survey Method, 2008

Table 4 Number of Presumed Eligible and Presumed Non-Eligible Respondents by Income Category Given Household Size, 2008

Table 5 Number and Percentage of Respondents of Reported Ethnicity by Survey Method, 2008

Table 6 Number and Percentage of Respondents by Reported Ethnicity, Presumed Eligibility, and Survey Method, 2008

Table 7 Number of Respondents Choosing Each Mode of Communication by Presumed Eligibility and Survey Method, 2008

Table 8 Number of Respondents by Service Provider and Survey Method, 2008

Table 9 Average Responses Regarding Monthly Bills, and Value of Landline and Cellular Services by Presumed Eligibility and Survey Method, 2008

Table 10 Average Responses Regarding Landline and Cellular Usage by Presumed Eligibility and Survey Method, 2008

Table 11 Reasons for Subscribing to Prepaid Cellular by Survey Method, 2008

Table 12 Reasons for Not Subscribing to Landline Service and Percentage of Respondents with Landline Service within the Past Five Years, by Presumed Eligibility and Survey Method, 2008 
Table 13 Average Percentages of Persons Indicating Knowledge of and Perceived Value of Lifeline by Survey Method, 2008

Table 14 Reported Reasons Respondents Aware of Lifeline Do Not Subscribe, 2008

Table 15 Reported Reasons Respondents Did Not Select the Option to Subscribe to Lifeline through DCF, 2008

Table A1 Number of Responses and Total Respondents Asked by Question and by Survey Method, 2008

Table B1 Maximum Household Income for Lifeline Eligibility in 2008

Table C1 Summary Statistics of Variables Used in Empirical Analysis, 2008 


\section{List of Graphs}

GRAPH

PAGE NUMBER

Graph 1 Percent of Respondents by Age Group for Each Survey Method, 2008

18

Graph 2 Comparison of Income Categories of Respondents by Survey Method, 2008 


\section{Table of Contents}

SECTIONS AND SUBSECTIONS

PAGE NUMBER

Acknowledgements

Executive Summary

ii

List of Tables

viii

List of Graphs

$\mathrm{X}$

I. Description and Background

I.A. Introduction

I.B. Low Participation

I.C. Previous PURC Studies

I.D. Summary of Current Research

II. Literature Survey $\quad 5$

III. Data Collection and Methodology $\quad 9$

III.A. Survey Descriptions 9

$\begin{array}{ll}\text { III.B. Data Management } & 13\end{array}$

IV. Statistics and Results $\quad 15$

IV.A. Demographics and Eligibility of Survey Respondents 15

IV.B. Preferences in Communications Services 23

IV.C. Choices of Service Providers $\quad 27$

IV.D. Value of Communications Services 29

$\begin{array}{ll}\text { V. Conclusion } & 40\end{array}$

References $\quad 43$

$\begin{array}{ll}\text { Appendix A } & 45\end{array}$

$\begin{array}{ll}\text { Appendix B } & 47\end{array}$

$\begin{array}{ll}\text { Appendix C } & 50\end{array}$ 


\section{Description and Background}

\section{I.A. Introduction}

Florida's Lifeline program is part of a nationwide program created by the Federal Communications Commission (FCC) in 1984 to provide monthly credits to low-income households for local telephone service. ${ }^{3}$ In Florida, the Lifeline program reduces a qualifying household's monthly telephone bill by up to $\$ 13.50 .{ }^{4}$ To qualify for Lifeline, a Florida household needs to meet only one of the eligibility criteria: (1) Receipt of Temporary Cash Assistance (TCA), Medicaid, Food Stamps, Supplemental Security Income (SSI), Low-Income Home Energy Assistance Program (LIHEAP), Section 8 Housing, or National School Lunch (NSL); (2) Have a household income that is no greater than 135 percent of the Federal Poverty Guideline (FPG); or (3) Participate in a Bureau of Indian Affairs Program. ${ }^{5}$

\footnotetext{
${ }^{3}$ MTS and WATS Market Structure, and Amendment of Part 67 of the Commission's Rules and Establishment of a Joint Board, Recommended Decision, CC Docket Nos. 78-72 and 80-286, 49 Fed. Reg. 48325 (rel. Nov. 23, 1984) (recommending the adoption of federal Lifeline assistance measures); MTS and WATS Market Structure, and Amendment of Part 67 of the Commission's Rules and Establishment of a Joint Board, Decision and Order, CC Docket Nos. 78-72 and 80-286, FCC 84-637, 50 Fed. Reg. 939 (rel. Dec. 28, 1984) (adopting the Joint Board's recommendation). Florida's program began in 1994. Florida Public Service Commission Order No. PSC-94-0242FOF-TL, issued on March 4, 1994.

${ }^{4}$ Some Lifeline participating households' phone bills in Florida show Lifeline credits greater than $\$ 13.50$. As part of telephone price rebalancing in Florida, BellSouth (now AT\&T), Sprint (now Embarq), and Verizon were restricted by statute from increasing local telephone prices for Lifeline customers. As Holt and Jamison (2006) explain, "BellSouth implemented this restriction by providing a credit on the bills for its Lifeline customers equal to the increase in local telephone prices that occurred with BellSouth's price rebalancing. Instead of providing a new credit on their customers' bills, Sprint and Verizon increased the Lifeline credit on the bills of their Lifeline customers, so the Lifeline credits to their customers' bills appear to exceed $\$ 13.50$.”

${ }^{5}$ The 135 percent criterion applies to AT\&T, Sprint/Embarq, and Verizon; other eligible telecommunications carriers are permitted to offer Lifeline to those with household income no greater than 125 percent of the FPG. Eligibility also can be obtained by participating in Bureau of Indian Affairs Programs (Tribal Temporary Assistance for Needy Families (TANF), Head Start subsidy, National School Lunch Free Lunch Program). These programs are based upon membership in a tribe that is formally enrolled with the federal Office of Tribal Services. As of March 2007, there are two tribes registered in Florida: the Miccosukee Tribe of Indians of Florida and the Seminole Tribe of Florida.
} 
A primary motive for developing the Lifeline program was a belief that the introduction of Subscriber Line Charges ${ }^{6}$ following the breakup of AT\&T would make basic local telephone service, provided by traditional landline telephone companies, unaffordable for low-income households. This belief was based on two assumptions that would seem to no longer apply. The first assumption was that low-income households would need a price discount to afford telephone service. As we explain later, several studies have shown that the discounts seem to have little bearing on low-income households' decisions to purchase telephone service. The second assumption was that landline local telephone service was essential for low-income households. We find in our study that many low-income households now choose to make cellular service their primary mode of telecommunications at a rate that exceeds that of higher-income households.

\section{I.B. Low Participation}

The lack of interest in Lifeline by Florida low-income households, combined with other factors such as lack of awareness of the program, has resulted in low participation rates ${ }^{7}$ by households that are eligible for the program. In 2005, Florida's combined participation rate for Lifeline and Link-Up ${ }^{8}$ was approximately 13.2 percent. At that time the income criterion was household income at or below 125 percent of FPG. Based on the current income criterion of 135 percent of FPG, the participation rate would have been 12.2 percent in 2005 . Under either

\footnotetext{
${ }^{6}$ Subscriber Line Charges are fees imposed by the FCC on customers of landline local telephone service to recover some of the costs for local telephone lines. Traditionally prices for local telephone service have not covered the entire cost of providing the line that provides the service.

${ }^{7}$ The participation rate is calculated as the number of households participating divided by the number of households eligible to participate.

${ }^{8}$ The Link-Up program reduces the cost of telephone installation by 50 percent, up to a maximum of $\$ 30$. That reduction assumes the form of a credit and is deducted from the service installation charge.
} 
income criteria, Florida's participation rate was less than one-half the FCC's estimated national participation rate of 38 percent (Holt and Jamison, 2006). The seemingly low participation rate in Florida's Lifeline program led state officials to consider the effectiveness of Florida's enrollment policies. While the enrollment policy was amended in 2007 to allow online enrollment and direct online access through Florida's Department of Children and Families (DCF) Offices, ${ }^{9}$ Florida's participation rate is still estimated to be relatively low, in the order of approximately 14 percent. (FPSC, 2007)

Policymakers, regulators, telecommunications companies, and consumer advocates share a desire to improve program effectiveness; therefore, AT\&T and Embarq commissioned the current study to attempt to ascertain why low-income Floridians continue to participate in Lifeline at a low rate.

\section{I.C. Previous PURC Studies}

Low participation rates in Lifeline and the future of Lifeline have been the subject of previous research ${ }^{10}$ undertaken by the Public Utility Research Center (PURC) at the University of Florida. Such prior research was funded by BellSouth Telecommunications, Inc. (now AT\&T) and Sprint-Florida, Inc. (now Embarq). Among other findings, this research showed that a lack of awareness of the program and a distrust of support programs were the most prevalent barriers to enrollment. Additionally, the research revealed that almost all low-income households in Florida (about 90 percent) had landline phones even though only a small percentage took advantage of the Lifeline program.

\footnotetext{
${ }^{9}$ DCF manages public assistance programs in Florida.

${ }^{10}$ See Holt and Jamison (2006, 2007), Hauge and Jamison (Forthcoming), Hauge et al. (2007), Hauge et al. (Forthcoming), Brown and Jamison (2005), Brown (2006a, 2006b, 2006c), and Williamson (2006).
} 
The surveys also found patterns in low-income households' choices that affect Lifeline participation. Among the results, researchers found that at the time 52.2 percent of low-income households had a cellular phone, about 44.8 percent had Internet access, and 59.1 percent had either cable television or Direct Broadcast Satellite. This finding was important in that it suggested that low-income households may use communications services that did not qualify for Lifeline, in particular, cellular service. Furthermore, the studies found that Lifeline participation rates were lower in areas where cellular penetration was higher, indicating that low-income households might prefer cellular phones to landline phones.

Low-income households' choices of communications services continue to evolve, and these changes in consumption might impact whether eligible households participate in the Lifeline program, which continues to focus on traditional landline phone service. Knowing whether demand is changing and, if so, how, is crucial for assessing the effectiveness of Lifeline enrollment procedures, for improving low-income households' access to telecommunications services, and for informing policymakers as they consider participation targets and mechanisms for assisting low-income households' access to telecommunications.

\section{I.D. Summary of Current Research}

The current research seeks to inform the discussion of Lifeline by addressing four fundamental questions, namely:

- How do enrollment procedures impact households' participation in Lifeline?

- What do eligible households understand from the enrollment efforts?

- How does low-income household use of wireless communications impact enrollment in Lifeline? 
- What communications services are low-income households and consumers in Florida purchasing and/or using?

We employ surveys and statistical analyses to study Floridians' participation in Lifeline and their choices for communications services. With respect to the surveys, three approaches were used: a survey of customers responding via landline phone, a survey of customers responding via cellular phone, and an intercept survey (i.e., an in-person interview) of individuals exiting two different DCF offices in Florida. The results of the surveys and statistical analyses are tabulated in the report below.

The remainder of this paper is organized as follows. We first present a review of the literature with respect to Lifeline and program participation. Next, we describe our data collection process and the methodology of our surveys. We then provide results of our statistical and empirical analyses of the data. Finally, we present a summary of our findings and conclude.

\section{Literature Survey}

There have been a few recent papers addressing Lifeline participation. A brief summary of such research begins with Rodini et al. (2003), who illustrate the relationship between mobile and fixed line phone service. Because mobile telephone pricing in the United States is not regulated, such pricing may indirectly impact Lifeline enrollment. Mobile providers generally are not required to participate in the Lifeline program, although increasingly providers are choosing to do so. ${ }^{11}$ Low-income households choosing between cellular and landline services may therefore preclude their own subscription into the Lifeline program through their choice of

\footnotetext{
${ }^{11}$ Alltel, for example, provides Lifeline-eligible customers a discounted prepaid cellular plan which starts at $\$ 16.70$ per month for 300 prepaid in-network minutes (accurate as of Jan. 1, 2008). Also participating in Lifeline in Florida are the wireless telecommunications providers NPCR, Inc. and Sprint Nextel.
} 
cellular telecommunications. Rodini et al. find that fixed line and mobile services are reasonable substitutes for one another, and that subsidies to wireline carriers for universal service may be unjustified. This finding is substantiated by our research in which we find low-income households have a statistically significant higher probability of owning a cellular rather than a landline phone. Specifically, we find the probability of owning a cellular phone is 89 percent among respondents in the lowest five income groups ( $\$ 0$ to $\$ 49,999$ annual income); the probability of owning a landline phone among similar respondents is 40 percent. $^{12}$

Currently, the Lifeline program is tangentially addressed in two areas of economic research: the effectiveness and importance of universal service in general, and the economics of participation in public assistance programs. Academic papers addressing federal assistance programs designed to increase telephone penetration rates have almost unanimously determined that such programs are ineffective and/or inefficient. For example, Rosston and Wimmer (2000) find that federal universal service programs have little effect on telephone penetration rates, adversely affect the market through large taxes, and adversely affect competition. Valletti et al. (2002) add that different groups of consumers are affected by universal service programs in different ways, so that determining the actual benefits to society overall is difficult. Our research corroborates Valletti et al. in that we find statistically significant differences between lowincome and non-low-income households with respect to perceived value of the Lifeline discount. Specifically, we find that for those respondents with household annual income less than $\$ 29,999$, being younger, male, and less educated are negatively and significantly correlated with the perceived value of the Lifeline discount. Conversely, for respondents with income greater than $\$ 29,999$, age and being male are positively and significantly correlated with perceived value of

\footnotetext{
${ }^{12}$ This result is statistically significant at .001 for cellular ownership. It is significant at .001 for landline ownership for the lowest income level, and at .01 for the second lowest income level.
} 
Lifeline. ${ }^{13}$ Regarding the cost-effectiveness of Lifeline specifically, Garbacz and Thompson $(1997,2002,2003)$ find that due to small elasticities of demand for participation in the Lifeline program, extremely large expenditures per household on promoting Lifeline are required to increase the telephone penetration rate. Moreover, these effects have increased over the last decade; they find the Lifeline program to be ineffective, costly, and approximately nine times more expensive than a more targeted program might be. Similarly, Eriksson et al. (1998) focus on targeted versus untargeted subsidies in considering policies to promote universal service and find that subsidies such as Lifeline are ineffective in the telecommunications industry. Our findings suggest that perhaps this is due to low-income households' telecommunications preferences.

With respect to participation in Lifeline, Burton et al. (2007) consider Lifeline participation across the United States and find that bureaucratic costs and restrictions some Lifeline programs impose on supplementary services (such as call waiting and caller ID) discourage enrollee participation. They consider the outreach efforts of incumbent telecommunications providers as well as enrollment procedures and eligibility criteria to show that the traditional explanations for lack of participation (rooted in stigma) may not hold for the Lifeline program. This finding supports the research of Hauge et al. (2007) that finds incumbents' efforts to enroll beneficiaries to be statistically significant.

There also is a large literature on participation in public assistance programs. Currie (2004) summarizes the literature with respect to the largest means-tested programs in the US. Research on participation in Food Stamps, Federal Public Housing Assistance (FPHA), Medicaid, NSL, SSI, and TANF is particularly relevant for our research, given that these public

\footnotetext{
${ }^{13}$ Estimates and $p$ values are available from the authors upon request; the values reported are significant at .001 .
} 
assistance programs are frequently used to prove eligibility for Lifeline. Studies of participation in other public assistance programs guide our statistical analyses and serve as useful references for our models. Generally, the papers find that participation in public assistance programs increases with the size of the entitlement and receipt of another benefit. Participation falls with age, education, income level, urban living, and work experience. Our findings contribute to this literature through differentiation of telecommunication preferences. Additionally, many studies searching for drivers of participation rates take into account intangible factors such as stigma and lack of information regarding the program, both of which would decrease participation in public assistance programs (see Moffitt, 1983; Hauge et al., 2007). Some research supports theories that either lack of information or simply a choice not to participate are dominant effects on participation in public assistance programs (Andrade et al., 2002). Still, there is a lack of theoretical research more formally addressing the issue.

With respect to lack of information, we have some prior evidence based on surveys conducted by PURC. ${ }^{14}$ These include interviews of Floridians in person and over the telephone, as well as written surveys of households that qualified but did not participate and those that qualified and had disconnected their telephone service. Lack of information was shown to be a main indicator of non-participation in Lifeline in Florida. With new enrollment procedures in place and continued promotional efforts by telephone providers and associated interest groups, lack of information should be a decreasing reason for lack of participation. One aim of the current research is to determine whether this is the case. We find that the income group with the greatest probability of respondents being aware of Lifeline was the group of those with annual

\footnotetext{
${ }^{14}$ See Brown and Jamison (2005) and Brown (2006a, 2006b, 2006c).
} 
income between $\$ 10,000$ and $\$ 19,999 .{ }^{15}$ Even among this group, however, the probability of awareness was approximately 26 percent. Awareness ranged from 9 percent to 26 percent, with an average awareness among all groups of only 18 percent. Furthermore, we find that awareness of Lifeline was not strongly correlated with subscribing. For respondents in the lowest income group (Less than $\$ 10,000$ annual household income) 68 percent reported subscribing; however, for those in the second lowest income group only 29 percent subscribed. The second aim of our research is to evaluate low-income households' choices of telecommunications services with respect to landline and cellular options. Our data and the methodology used to undertake this research are explained next.

\section{Data Collection and Methodology}

\section{A. Survey Descriptions}

The primary source of data for this report is three surveys designed by the authors and implemented by the Bureau of Economic and Business Research (BEBR) at the University of Florida. The use of survey instruments was required since no existing database provided detailed data on telecommunications purchases across all demographic categories and both primary forms of voice telecommunications (landline and cellular). The surveys consisted of three methods of implementation: calls to landline phones, calls to cellular phones, and in-person interviews called intercept surveys. The questions asked in these surveys addressed the respondent's knowledge of Lifeline, experiences enrolling in Lifeline, communications services used, value placed on services, and household characteristics. If a respondent to the survey qualified for Lifeline and

\footnotetext{
${ }^{15}$ Our surveys asked respondents to indicate which annual income range their household would fall into. The income ranges were: Less than $\$ 10,000 ; \$ 10,000$ to $\$ 19,999 ; \$ 20,000$ to $\$ 29,999 ; \$ 30,000$ to $\$ 39,999 ; \$ 40,000$ to $\$ 49,999 ; \$ 50,000$ to $\$ 59,999 ; \$ 60,000$ to $\$ 79,999 ; \$ 80,000$ to $\$ 99,999 ; \$ 100,000$ to $\$ 150,000$; and Over $\$ 150,000$.
} 
was not enrolled, the respondent was given the opportunity to enroll by being placed in contact with the Florida Public Service Commission (FPSC) or their telephone provider to complete the enrollment. The landline survey required on average 7.8 minutes of the respondent's time to complete; the cellular survey required on average 9.5 minutes to complete; and the intercept survey required on average 6.2 minutes to complete. ${ }^{16}$ We obtained 970 completed telephone surveys (491 landline and 479 cellular phone) from all types of households, not just low-income households. We also obtained 208 completed intercept surveys. Having both low-income households and non-low-income households in the surveys is important for analyzing how lowincome households differ from the general population, if at all.

Questions for the landline telephone survey were identical to the cellular phone survey including the opportunity to enroll in Lifeline if the respondent was eligible and had not enrolled. Because there was a risk that consumers would be reluctant to answer the survey questions due to charges for incoming calls, we offered respondents completing a cellular survey a $\$ 10$ gift card to WalMart.

Our rationale for offering two types of phone surveys (landline and cellular) derives from our presupposition that persons who rely solely on cellular phones might differ from the rest of the population in terms of their demographic characteristics. This presupposition is borne out by our results that appear in Table 3 and Table 5 below. The tables show that respondents to the cellular survey tend to be younger, and the proportion of Hispanic respondents is greater in the cellular survey. To avoid biased results, it was necessary to ensure an adequate number of respondents to both types of surveys, in order to account for likely differences in the populations that would be relevant for our study. A study by the Pew Research Center confirms that the

\footnotetext{
${ }^{16}$ Average time provided by BEBR based on computer-recorded completion times for all surveys. For more detailed information please contact the authors.
} 
improved demographic representation for certain groups provides benefits that offset the increased costs of cellular surveys and asserts that exclusion of those relying solely on cellular phones would call into question the credibility of survey results (Pew, 2008).

The intercept survey targeted persons leaving Florida DCF offices in Jacksonville and Miami. The questions for this survey were identical to the telephone surveys with the exception of the inclusion of questions regarding the person's experiences in learning about or signing up for Lifeline at the DCF office. Specifically, we added questions about what the person learned about Lifeline during the DCF visit, whether the person enrolled in Lifeline (if he or she was not already enrolled), and the factors affecting the decision to enroll or not enroll.

The two phone-based surveys were conducted during the period from December 7, 2007 through February 1, 2008, and consisted of random digit dialing across the state of Florida. For all survey methods, respondents were given an option to complete the survey in Spanish; for the phone-based surveys, Spanish speaking surveyors were always on hand, and all intercept surveyors were bilingual in English and Spanish. In our data, 5.1 percent of landline respondents, 5.7 percent of cellular respondents, and 2.4 percent of intercept respondents completed the survey in Spanish.

The intercept survey was conducted in January $2008 .{ }^{17}$ In both Jacksonville and Miami, surveyors interviewed persons exiting a DCF office, a location chosen for its relatively high proportion of persons from low-income households. We targeted DCF offices in cities to ensure there would be enough potential respondents to provide a viable survey. We chose Jacksonville and Miami to ensure that the sample covered both south Florida and north Florida. While this

\footnotetext{
${ }^{17}$ The Jacksonville DCF Office is in Duval county (DCF District 4), located at 5920 Arlington Expressway, Jacksonville, FL 32211-0083. Surveys were conducted on January 3, 4, 7, 8, 9, and 14, 2008. The Miami DCF Office is in Dade county (DCF District 11), located at 401 NW $2^{\text {nd }}$ Avenue, North Tower 1007, Miami, FL 33128. Surveys were conducted January 7 - 11, 2008.
} 
ensured a sufficient number of low-income (and therefore potentially Lifeline-eligible) persons would be interviewed, it also introduced the possibility of sample selection bias. In Table 1, we compare relevant demographic statistics for the entire state of Florida with those for Jacksonville and Miami, and for the counties in which the two cities are located.

Table 1

Comparison of Demographic Statistics among the State of Florida, Duval County, and Miami-Dade County, 2003 and $2006{ }^{18}$

\begin{tabular}{|l|c|c|c|c|c|}
\hline $\begin{array}{l}\text { Demographic } \\
\text { Statistic* }\end{array}$ & Florida & $\begin{array}{c}\text { Duval } \\
\text { County }\end{array}$ & $\begin{array}{c}\text { City of } \\
\text { Jacksonville }\end{array}$ & $\begin{array}{c}\text { Miami-Dade } \\
\text { County }\end{array}$ & $\begin{array}{c}\text { City of } \\
\text { Miami }\end{array}$ \\
\hline Population (persons) & $18,089,888$ & 837,964 & 794,555 & $2,402,208$ & 376,815 \\
\hline Percent Urban & $89.0 \%$ & $96.0 \%$ & $\mathrm{n} / \mathrm{a}$ & $99.3 \%$ & $\mathrm{n} / \mathrm{a}$ \\
\hline $\begin{array}{l}\text { Median Household } \\
\text { Income }\end{array}$ & $\$ 40,900$ & $\$ 41,736$ & $\$ 40,316$ & $\$ 34,682$ & $\$ 23,483$ \\
\hline Per Capita Income & $\$ 21,557$ & $\$ 20,753$ & $\$ 20,337$ & $\$ 18,497$ & $\$ 15,128$ \\
\hline $\begin{array}{l}\text { Percent Population } \\
\text { Below Poverty }\end{array}$ & $11.9 \%$ & $11.7 \%$ & $12.2 \%$ & $17.1 \%$ & $28.5 \%$ \\
\hline $\begin{array}{l}\text { Population per } \\
\text { Square Mile }\end{array}$ & 335 & 1,083 & 1,048 & 1,234 & 10,467 \\
\hline
\end{tabular}

* 2006 data for state and county figures; 2003 for city figures; dollars are nominal.

While Jacksonville and Duval County appear relatively similar to Florida as a whole, the city of Miami and Miami-Dade County appear less so. More specifically, average incomes and percent of population below poverty for persons and households in Jacksonville and Duval County are similar to those for the state. In contrast, persons and households in Miami and Miami-Dade County have lower incomes and have nearly double the rate of poverty. To test whether the differences pose a significant obstacle to our analyses, we measure whether the

\footnotetext{
${ }^{18}$ Data obtained from the US Census Bureau, available at http://quickfacts.census.gov, accessed January 29, 2008.
} 
percents of the population below poverty within Duval County and within Miami-Dade County are statistically significantly different from the percent population below poverty of all other counties within the state (rather than simply comparing the degree of poverty to the state average). We find that the differences are not statistically significant; therefore, we make no adjustments to our analyses that follow.

To ensure the accuracy and anonymity of the survey implementation across all surveyors, BEBR managers trained each surveyor specifically on this survey. In addition, BEBR pre-tested all three surveys to ensure there were no errors in the survey programming and no confusing questions or other communications issues between the surveyor and respondent, and to ensure consistency across surveyors. Finally, all surveyors from the phone survey were randomly monitored by BEBR managers for quality control.

\section{B. Data Management}

For each of the phone and intercept surveys, BEBR designed a software program to allow surveyors to enter responses directly into a database and to easily navigate the survey based on the responses. This resulted in a different subset of questions to be asked to different respondents based on those respondents' prior answers. For example, a respondent stating he had only a landline phone was not asked questions pertaining to his cellular telephone usage. The software program was designed to minimize errors that may result from human error of surveyors. Once a survey was completed, the responses were automatically transferred to the central database where they were compiled and organized without additional data entry, again eliminating the possibility of errors from manual data entry. Finally, the compiled database for each of the three survey methods was converted and exported into a statistical package (STATA 10) for analysis. 
Once the survey data was transferred into STATA 10, it was tested for response accuracy. This was accomplished by looking at outliers in the responses, mean values, median values, standard deviations, and minimum and maximum values. Outliers were scrutinized as they typically are a leading indication of an incorrect or invalid response. The source of incorrect responses could be due to the following: (1) an error by the surveyor in recording a legitimate response, (2) an error by the respondent due to a misunderstanding of the question, and/or (3) an error by the respondent due to intent to exaggerate or refusal to report an accurate response. It is not possible to determine in all cases whether an outlier falls into one or more of the categories above or whether a response was in fact a truthful response, and hence, a true outlier. Further, it is not possible to determine in all cases whether a non-outlier response is an incorrect response. As a result, we limit any manual corrections of responses perceived to be possibly incorrect, conservatively, by deleting only those responses that are beyond the $99^{\text {th }}$ percentile of the range of responses and are clearly beyond reason. Out of 970 observations from the phone surveys, this resulted in five observations being dropped, leaving a total of 965 completed valid phone survey responses. ${ }^{19}$

Another data issue to be addressed occurred when a respondent was uncertain how to answer a question or refused to answer a question. Surveyors were instructed to indicate for each question whether a respondent chose one of these options, i.e., a "don't know" or a "refused" response. Such responses are often genuine, when survey respondents are not aware of specifics relating to their telephone usage; for example, one's total usage or monthly bill if that person is not the person typically handling such documents. A refusal to respond was more common in

\footnotetext{
${ }^{19}$ Two landline survey respondents and three cellular survey respondents more than once chose answers that were mutually exclusive and provided at least one response beyond the $99^{\text {th }}$ percentile range of reasonable responses. These observations, therefore, were excluded in their entirety.
} 
response to demographic questions such as age, ethnicity, and income. To account for “don't know" and "refused" responses, the particular response that was unknown or refused was excluded for that observation. The total number of observations as reported in the following tables therefore will differ by question due to such responses. This does not affect the integrity of the data or results.

In sum, the total number of valid completed phone surveys in this study is 965 , of which 489 are obtained from calls to landline phones and 476 were obtained from calls to cellular phones. An additional 208 surveys were obtained from intercept interviews (103 from Jacksonville and 105 from Miami). The response rate for total completed observations is 44.1 percent for landline surveys and 31.0 percent for cellular surveys. ${ }^{20}$ Details of the survey results are provided next.

\section{Statistics and Results}

\section{A. Demographics and Eligibility of Survey Respondents}

We begin by describing the demographic makeup of the survey respondents, reported in Table 2. (Details on response rates per question are provided in Appendix A.)

Comparing demographic statistics between phone surveys and intercept surveys, several significant differences exist. Intercept survey respondents were more likely to be women, to be younger on average, to rent their residence, and to have larger household size and more children. These differences are statistically significant, meaning there is a very high probability that the variations are not simply due to random sampling. ${ }^{21}$ These demographics may correlate with the

\footnotetext{
20 The response rate is calculated using the total number of calls connecting to a person who then had the opportunity to participate in the survey or to decline to participate.

${ }^{21}$ Based on a two-sample mean comparison test, these differences are statistically significant across all comparisons at any level greater than 0.1 percent.
} 
intercept survey respondents having lower income than the phone survey respondents on average. $^{22}$ In addition, some demographic variables differ between the landline and cellular survey. In particular, the average age of respondents to the cellular survey is lower than the sample mean age of respondents for the landline survey, perhaps indicating that younger people prefer cellular over landline for voice communications.

Table 2

Sample Means for Each Demographic Indicator by Survey Method, 2008

\begin{tabular}{|l||c|c|c|}
\hline Demographic & $\begin{array}{c}\text { Landline } \\
\text { Survey }\end{array}$ & $\begin{array}{c}\text { Cellular } \\
\text { Survey }\end{array}$ & $\begin{array}{c}\text { Intercept } \\
\text { Survey }\end{array}$ \\
\hline Percent Female & $61.7 \%$ & $50.0 \%$ & $82.7 \%$ \\
\hline Age (in years) & 53.8 & 40.8 & 35.5 \\
\hline $\begin{array}{l}\text { Percent Who Own Their } \\
\text { Residence }\end{array}$ & $85.3 \%$ & $57.1 \%$ & $19.3 \%$ \\
\hline $\begin{array}{l}\text { Total Number of Persons } \\
\text { in Household }\end{array}$ & 2.6 & 3.2 & 3.4 \\
\hline $\begin{array}{l}\text { Average No. of Children } \\
\text { under Age 18 in Household }\end{array}$ & 0.5 & 0.9 & 1.4 \\
\hline
\end{tabular}

Our age-related findings are shown in greater detail in Table 3 and Graph 1. Table 3 shows the number of surveys collected by various age groups. Graph 1 plots the percent distribution of respondents by age group for each survey method and shows that the cellular survey respondents are similar to the intercept survey respondents in terms of the distribution of respondents by age groups. The vertical axis shows percentages of respondents and the horizontal axis shows age groups of respondents. Landline respondents tended to be older than the cellular and intercept survey respondents.

${ }^{22}$ See Table 4. 
Table 3

Number of Respondents by Age

Group for Each Survey Method, 2008 ${ }^{23}$

\begin{tabular}{|l||c|c|c|}
\hline \multirow{2}{*}{\multicolumn{1}{|c||}{ Age Groups }} & \multicolumn{3}{c|}{ Numbers of Respondents } \\
\cline { 2 - 4 } & $\begin{array}{c}\text { Landline } \\
\text { Survey }\end{array}$ & $\begin{array}{c}\text { Cellular } \\
\text { Survey }\end{array}$ & $\begin{array}{c}\text { Intercept } \\
\text { Survey }\end{array}$ \\
\hline \multirow{2}{*}{$18-24$ Years Old } & 26 & 90 & 52 \\
& $5.3 \%$ & $18.9 \%$ & $25.0 \%$ \\
\hline \multirow{2}{*}{$25-54$ Years Old } & 205 & 286 & 136 \\
& $41.9 \%$ & $60.1 \%$ & $65.4 \%$ \\
\hline \multirow{2}{*}{$55-74$ Years Old } & 187 & 75 & 18 \\
& $38.2 \%$ & $15.8 \%$ & $8.7 \%$ \\
\hline \multirow{2}{*}{ Over 74 Years Old } & 53 & 16 & 0 \\
& $10.8 \%$ & $3.4 \%$ & $0.0 \%$ \\
\hline \multirow{2}{*}{ Did Not Answer } & 18 & 9 & 2 \\
& $3.7 \%$ & $1.9 \%$ & $1.0 \%$ \\
\hline Total & $\mathbf{4 8 9}$ & $\mathbf{4 7 6}$ & $\mathbf{2 0 8}$ \\
\hline
\end{tabular}

A central focus of this report is the analysis of telecommunications choices among lowincome households. Graph 2 compares the household incomes for the respondents in the three surveys. The horizontal axis shows the income categories from the surveys and the vertical axis shows the percent of respondents who said they were in these categories. The respondents in the intercept survey have statistically significant lower incomes than the respondents in the other two surveys. ${ }^{24}$ This is expected because the phone surveys sampled a cross section of Floridians with phones, while the intercept survey samples only Floridians who visited DCF offices. The cellular

\footnotetext{
${ }^{23}$ Note that the ages represent the age of the respondent, not the age of the head of household (as in Holt and Jamison, 2006.)

${ }^{24}$ The level of significance is 0.1 percent.
} 
survey appeared to capture persons with slightly lower incomes than did the landline survey, but the differences are small. A broad conclusion from Graphs 1 and 2 is that the phone surveys generally captured higher income households than did the intercept survey, while the intercept and cellular surveys generally captured younger people than did the landline survey.

\section{Graph 1}

Percent of Respondents by Age Group for Each Survey Method, 2008

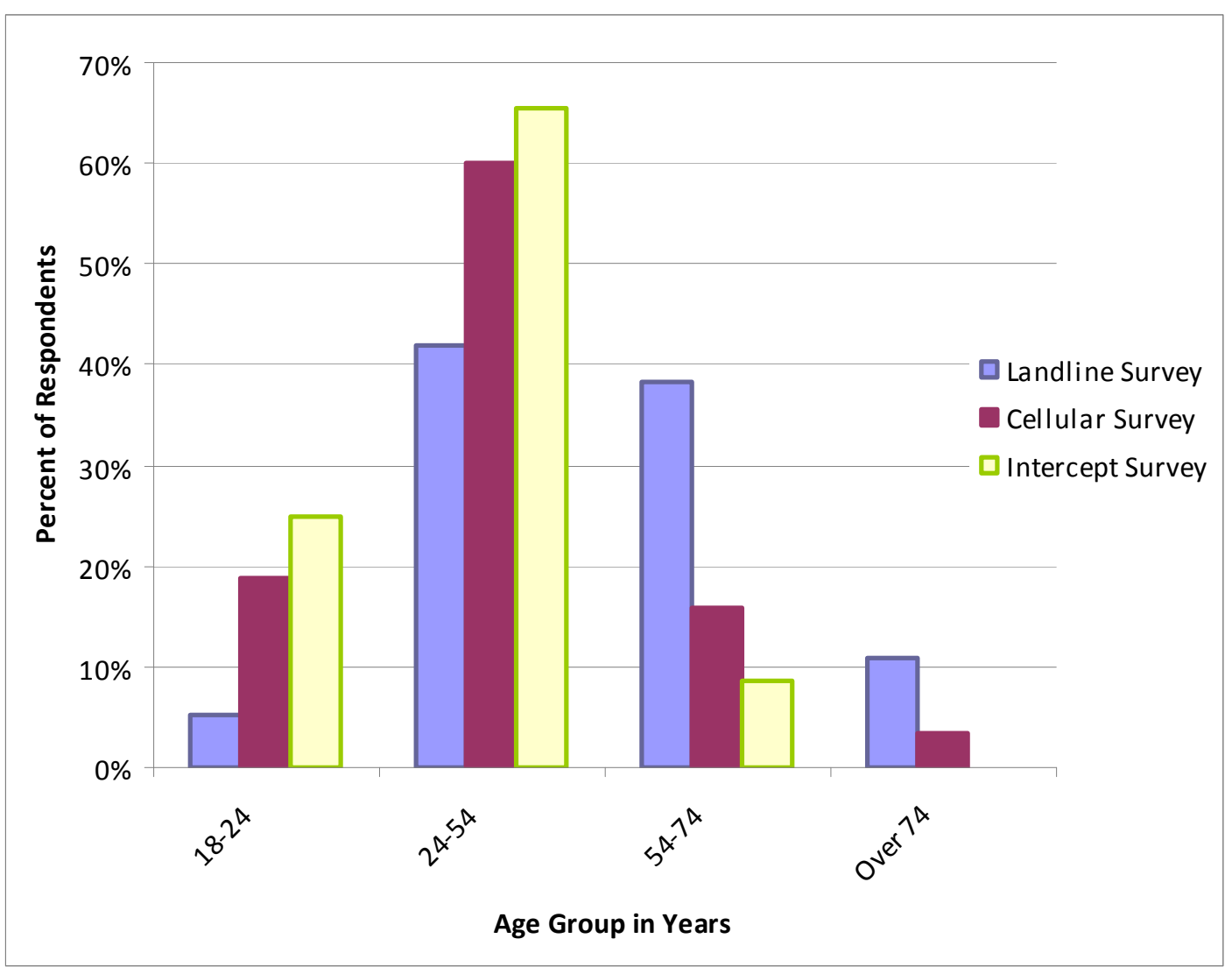




\section{Graph 2}

Comparison of Income Categories of Respondents by Survey Method, 2008

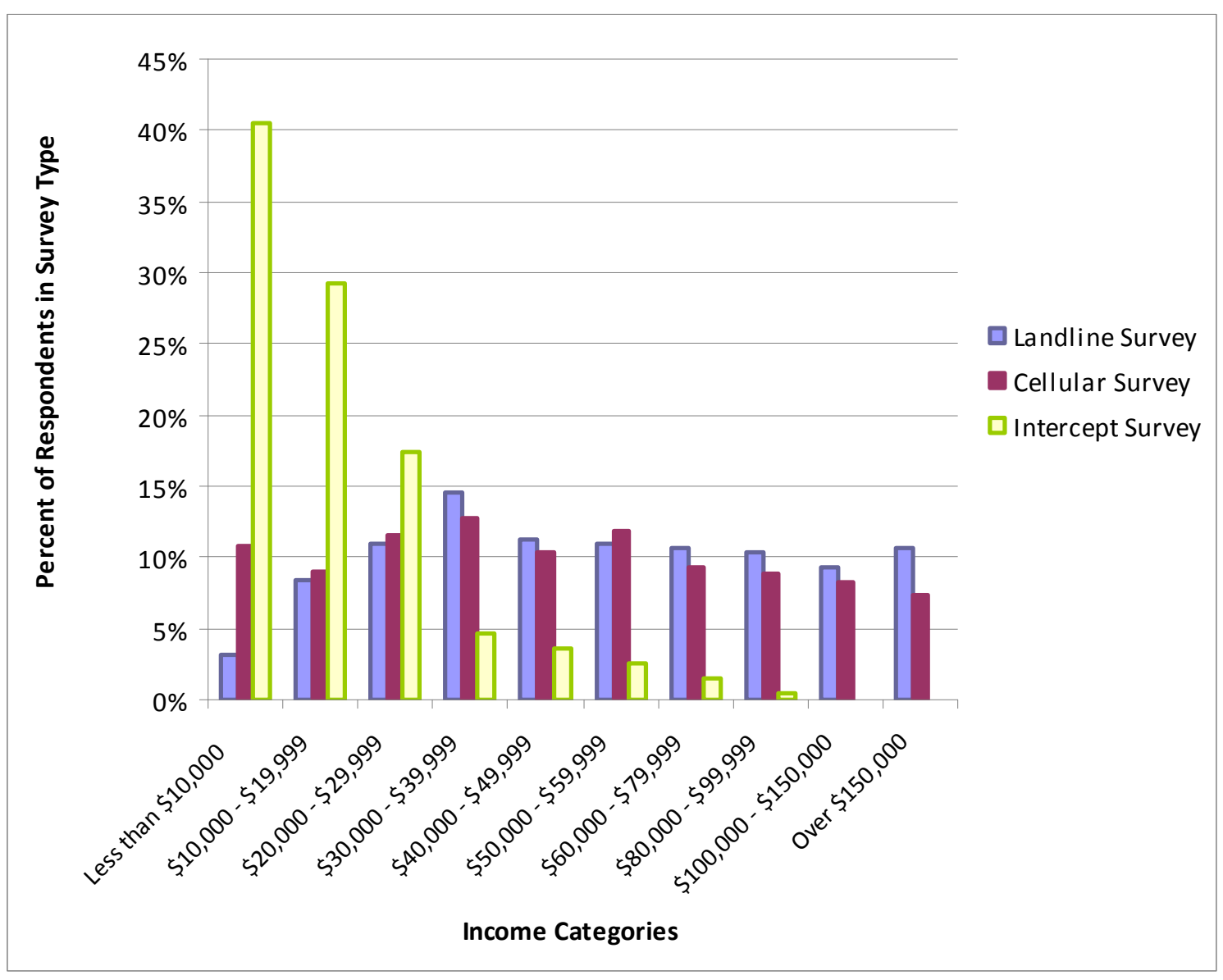

Next, to focus on eligibility for the Lifeline program, we first define a low-income household based on the FPG that associates low-income status by household size and income. We are able to classify our respondents as low-income or not low-income given their reported household size and responses to a request to report their income within a specific incremental range. We use the smallest feasible increment that maximized the probability of obtaining a truthful and accurate response from our target group of low-income persons: increments of $\$ 10,000$ from income of $\$ 0$ to income of $\$ 59,999$, and larger increments above $\$ 59,999$. Because we focus on the eligibility of respondents to qualify for the Lifeline program, we define low- 
income households as those who would qualify for Lifeline based on their reported household size and reported income relative to 135 percent of the FPG, and we label these respondents as "presumed eligible." 25 This is done using household size along with the mid-point of each income range to create the parameters defining presumed eligibility based on the eligibility guidelines specified by the Lifeline program. ${ }^{26}$ Using this approach, we define the parameters for presumed eligibility as follows:

1. All household sizes with reported income less than $\$ 10,000$

2. Household sizes of 2 or more with reported income less than $\$ 20,000$

3. Household sizes of 4 or more with reported income less than $\$ 30,000$

4. Household sizes of 6 or more with reported income less than $\$ 40,000$

5. Household sizes of 8 or more with reported income less than $\$ 50,000$

6. Household sizes of 10 or more with reported income less than $\$ 60,000$

Table 4 shows the number of presumed eligible and presumed non-eligible respondents that fall within each reported income category. It indicates that respondents in the cellular survey were more likely to be from households presumed eligible for Lifeline than those in the landline survey: 25 percent of the cellular respondents are presumed eligible, while only 14 percent of the landline respondents are presumed eligible. This is consistent with results shown in Graph 2. The intercept survey respondents were concentrated even more in presumably eligible households; over 90 percent of the intercept survey respondents are presumed eligible.

\footnotetext{
${ }^{25}$ Actual eligibility guidelines for Lifeline are provided in Appendix B.

${ }^{26}$ For example, to qualify for Lifeline in 2008, a household of three persons must have an annual income less than $\$ 23,760$. If the respondent from that household selects the annual income increment of $\$ 20,000-\$ 30,000$, we do not know for certain whether he qualifies for Lifeline. If his income is below $\$ 23,760$, he does; if it is above, he does not. To classify this individual as eligible for Lifeline or non-eligible, we use the mid-point of the reported range: in this case $\$ 25,000$. Because an income of $\$ 25,000$ would render this individual non-eligible for Lifeline, we categorize him as presumed non-eligible.
} 
Table 4

Number of Presumed Eligible and Presumed Non-Eligible Respondents by Income Category Given Household Size, 2008

\begin{tabular}{|c|c|c|c|c|c|c|}
\hline \multirow[b]{2}{*}{ Income Category } & \multicolumn{2}{|c|}{ Landline Survey } & \multicolumn{2}{|c|}{ Cellular Survey } & \multicolumn{2}{|c|}{ Intercept Survey } \\
\hline & $\begin{array}{c}\text { Presumed } \\
\text { Eligible }\end{array}$ & $\begin{array}{l}\text { Presumed } \\
\text { Non-Elig }\end{array}$ & $\begin{array}{l}\text { Presumed } \\
\text { Eligible }\end{array}$ & $\begin{array}{l}\text { Presumed } \\
\text { Non-Elig }\end{array}$ & $\begin{array}{c}\text { Presumed } \\
\text { Eligible* }\end{array}$ & $\begin{array}{c}\text { Presumed } \\
\text { Non-Elig }\end{array}$ \\
\hline Less than $\$ 10,000$ & $\begin{array}{l}11 \\
22 \%\end{array}$ & $\begin{array}{l}0 \\
0.0 \% \\
\end{array}$ & $\begin{array}{l}43 \\
43 \%\end{array}$ & $\begin{array}{l}0 \\
0.0 \% \\
\end{array}$ & $\begin{array}{l}79 \\
44.4 \%\end{array}$ & $\begin{array}{l}0 \\
0.0 \%\end{array}$ \\
\hline$\$ 10,000-\$ 19,999$ & $\begin{array}{l}21 \\
42 \%\end{array}$ & $\begin{array}{l}9 \\
2.9 \%\end{array}$ & $\begin{array}{l}29 \\
29 \%\end{array}$ & $\begin{array}{l}7 \\
2.4 \%\end{array}$ & $\begin{array}{l}57 \\
32.0 \%\end{array}$ & $\begin{array}{l}0 \\
0.0 \%\end{array}$ \\
\hline$\$ 20,000-\$ 29,999$ & $\begin{array}{l}12 \\
24 \%\end{array}$ & $\begin{array}{l}27 \\
8.8 \%\end{array}$ & $\begin{array}{l}20 \\
20 \%\end{array}$ & $\begin{array}{l}26 \\
8.7 \%\end{array}$ & $\begin{array}{l}28 \\
15.7 \%\end{array}$ & $\begin{array}{c}6 \\
35.3 \%\end{array}$ \\
\hline$\$ 30,000-\$ 39,999$ & $\begin{array}{l}4 \\
8 \%\end{array}$ & $\begin{array}{l}48 \\
15.6 \%\end{array}$ & $\begin{array}{l}5 \\
5 \%\end{array}$ & $\begin{array}{l}46 \\
15.4 \%\end{array}$ & $\begin{array}{l}7 \\
3.9 \%\end{array}$ & $\begin{array}{c}2 \\
11.8 \%\end{array}$ \\
\hline$\$ 40,000-\$ 49,999$ & $\begin{array}{l}2 \\
4 \% \\
\end{array}$ & $\begin{array}{l}38 \\
12.4 \%\end{array}$ & $\begin{array}{l}3 \\
3 \% \\
\end{array}$ & $\begin{array}{l}38 \\
12.8 \%\end{array}$ & $\begin{array}{l}5 \\
2.8 \% \\
\end{array}$ & $\begin{array}{c}2 \\
11.8 \% \\
\end{array}$ \\
\hline$\$ 50,000-\$ 59,999$ & $\begin{array}{l}0 \\
0.0 \%\end{array}$ & $\begin{array}{l}39 \\
12.7 \%\end{array}$ & $\begin{array}{l}0 \\
0.0 \%\end{array}$ & $\begin{array}{l}47 \\
15.8 \%\end{array}$ & $\begin{array}{l}2 \\
1.1 \%\end{array}$ & $\begin{array}{c}3 \\
17.6 \%\end{array}$ \\
\hline$\$ 60,000$ - $\$ 79,999$ & $\begin{array}{l}0 \\
0.0 \%\end{array}$ & $\begin{array}{l}38 \\
12.4 \%\end{array}$ & $\begin{array}{l}0 \\
0.0 \%\end{array}$ & $\begin{array}{l}37 \\
12.4 \%\end{array}$ & $\begin{array}{l}0 \\
0.0 \%\end{array}$ & $\begin{array}{c}3 \\
17.6 \%\end{array}$ \\
\hline$\$ 80,000-\$ 99,999$ & $\begin{array}{l}0 \\
0.0 \% \\
\end{array}$ & $\begin{array}{l}37 \\
12.1 \% \\
\end{array}$ & $\begin{array}{l}0 \\
0.0 \% \\
\end{array}$ & $\begin{array}{l}35 \\
11.7 \% \\
\end{array}$ & $\begin{array}{l}0 \\
0.0 \% \\
\end{array}$ & $\begin{array}{l}1 \\
5.9 \% \\
\end{array}$ \\
\hline $\begin{array}{l}\$ 100,000- \\
\$ 150,000\end{array}$ & $\begin{array}{l}0 \\
0.0 \%\end{array}$ & $\begin{array}{l}33 \\
10.7 \%\end{array}$ & $\begin{array}{l}0 \\
0.0 \% \\
\end{array}$ & $\begin{array}{l}33 \\
11.1 \%\end{array}$ & $\begin{array}{l}0 \\
0.0 \% \\
\end{array}$ & $\begin{array}{l}0 \\
0.0 \%\end{array}$ \\
\hline Over $\$ 150,000$ & $\begin{array}{l}0 \\
0.0 \% \\
\end{array}$ & $\begin{array}{l}38 \\
12.4 \% \\
\end{array}$ & $\begin{array}{l}0 \\
0.0 \% \\
\end{array}$ & $\begin{array}{l}29 \\
9.7 \% \\
\end{array}$ & $\begin{array}{l}0 \\
0 / 0 \% \\
\end{array}$ & $\begin{array}{l}0 \\
0.0 \% \\
\end{array}$ \\
\hline Total** & 50 & 307 & 100 & 298 & 178 & 17 \\
\hline
\end{tabular}

* The number of presumed eligible respondents in the intercept survey was based not only on reported household income and household size, but also whether the respondent applied for any of the qualifying government assistance programs that would make him or her eligible for Lifeline.

** There were 132 landline, 78 cellular, and 13 intercept respondents who did not report their household incomes.

Table 5 summarizes the reported ethnicity of the respondents. The data indicate that the cellular survey had higher proportions of black and Hispanic respondents than did the landline survey. The intercept survey had a higher proportion of black respondents than the cellular 
survey, but approximately the same proportion of Hispanic respondents as the two phone surveys.

Table 6 further analyzes the ethnic makeup of the survey respondents and compares ethnicity with the proportions of presumed eligible and non-eligible respondents. The data indicate that the cellular survey had higher proportions of presumed eligible black, white, and Hispanic respondents than did the landline survey. The proportions of white and Hispanic respondents that are presumed eligible in the intercept survey are higher than the comparable proportion of black respondents in the same survey, but the differences are statistically insignificant.

Table 5

Number and Percentage of Respondents of Reported Ethnicity by Survey Method, 2008

\begin{tabular}{|l||c|c|c|c|c|c|}
\hline \multirow{2}{*}{ Ethnicity } & \multicolumn{6}{|c|}{ Respondents } \\
\cline { 2 - 7 } & Lumber & Percentage & Number & Percentage & Number & Percentage \\
\hline \multirow{2}{*}{ White } & 378 & $78.2 \%$ & 284 & $58.1 \%$ & 58 & $26.9 \%$ \\
\hline Black & 36 & $7.5 \%$ & 79 & $16.2 \%$ & 94 & $43.5 \%$ \\
\hline Hispanic & 50 & $10.4 \%$ & 97 & $19.8 \%$ & 42 & $19.4 \%$ \\
\hline Asian & 7 & $1.4 \%$ & 10 & $2.0 \%$ & 3 & $1.4 \%$ \\
\hline $\begin{array}{l}\text { Native } \\
\text { American }\end{array}$ & 7 & $1.4 \%$ & 9 & $1.8 \%$ & 7 & $3.2 \%$ \\
\hline Other & 5 & $1.0 \%$ & 10 & $2.0 \%$ & 12 & $5.6 \%$ \\
\hline Total & 483 & $100 \%$ & 489 & $100 \%$ & 216 & $100 \%$ \\
\hline
\end{tabular}

In summary, we find that the landline survey respondents tended to have higher incomes than the cellular or intercept survey respondents, with the intercept survey respondents tending to 
have much lower incomes on average than the respondents of the other two surveys. Landline survey respondents also tended to be older than the cellular and intercept survey respondents. The cellular and intercept survey respondents were more likely to be from minority groups black and Hispanic respondents - who, based on reported household income, were also more likely to be eligible for Lifeline discounts.

\section{Table 6}

Number and Percentage of Respondents by Reported Ethnicity, Presumed Eligibility, and Survey Method, 2008

\begin{tabular}{|c|c|c|c|c|c|c|c|c|c|}
\hline \multirow{4}{*}{ Ethnicity } & \multicolumn{9}{|c|}{ Number or Percent of Respondents } \\
\hline & \multicolumn{3}{|c|}{ Landline Survey } & \multicolumn{3}{|c|}{ Cellular Survey } & \multicolumn{3}{|c|}{ Intercept Survey } \\
\hline & \multirow[t]{2}{*}{ Number } & \multicolumn{2}{|c|}{$\begin{array}{l}\text { Presumed } \\
\text { Eligible? }\end{array}$} & \multirow[t]{2}{*}{ Number } & \multicolumn{2}{|c|}{$\begin{array}{l}\text { Presumed } \\
\text { Eligible? }\end{array}$} & \multirow[t]{2}{*}{ Number } & \multicolumn{2}{|c|}{$\begin{array}{l}\text { Presumed } \\
\text { Eligible? }\end{array}$} \\
\hline & & $\%$ Yes & $\%$ No & & $\%$ Yes & $\%$ No & & $\%$ Yes & $\%$ No \\
\hline White & 282 & $9.9 \%$ & $90.1 \%$ & 238 & $17.7 \%$ & $82.3 \%$ & 56 & $92.9 \%$ & $7.1 \%$ \\
\hline Black & 31 & $29.0 \%$ & $71.0 \%$ & 71 & $36.6 \%$ & $63.4 \%$ & 93 & $89.2 \%$ & $10.8 \%$ \\
\hline Hispanic & 36 & $25.0 \%$ & $75.0 \%$ & 82 & $37.9 \%$ & $62.1 \%$ & 41 & $95.1 \%$ & $4.9 \%$ \\
\hline Asian & 5 & $39.2 \%$ & $60.8 \%$ & 10 & $20.1 \%$ & $79.9 \%$ & 3 & $65.7 \%$ & $34.3 \%$ \\
\hline $\begin{array}{l}\text { Native } \\
\text { American }\end{array}$ & 3 & $35.5 \%$ & $64.5 \%$ & 8 & $24.8 \%$ & $75.2 \%$ & 7 & $100.0 \%$ & $0.0 \%$ \\
\hline Other & 3 & $68.2 \%$ & $31.8 \%$ & 6 & $0.0 \%$ & $100.0 \%$ & 11 & $90.9 \%$ & $9.1 \%$ \\
\hline Total & 360 & $14.2 \%$ & $85.8 \%$ & 415 & $24.8 \%$ & $75.2 \%$ & 211 & $91.5 \%$ & $8.5 \%$ \\
\hline
\end{tabular}

\section{B. Preferences in Communications Services}

Next, we turn to the modes of communications used by respondents in each survey. Table

7 presents the total number of respondents with landline and cellular phones, along with a 
summary of respondents who use only landline, only cellular, both landline and cellular phones, and neither form of communications.

Based on the data in Table 7, 56.3 percent of cellular survey respondents subscribe to a landline phone, and 47.1 percent of the intercept survey respondents subscribe to a landline phone. Furthermore, 83.2 percent of landline survey respondents subscribe to a cellular phone, and 76 percent of intercept survey respondents subscribe to a cellular phone. This means that of respondents reached by a means other than a landline phone, only about one-half had a landline phone, but of those reached by a means other than a cellular phone, over three-fourths had a cellular phone. This would imply that cellular phones are becoming the preferred mode of voice communications.

The data also reflect a growing trend in that those who subscribe only to one form of communication (landline or cellular phone) are increasingly choosing a cellular phone. Only 16.4 percent of landline survey respondents and 14.4 percent of intercept survey respondents purchased only landline service. In contrast, 43.7 percent of cellular respondents and 43.3 percent of intercept respondents reported having only a cellular phone. Interestingly, among lowincome households, the probability of owning a cellular phone (either alone or in addition to a landline phone) is statistically dependent only on household income; age, reported value of the service, gender, home ownership, race, and ethnicity are not statistically significant determinants of cellular phone ownership. However, among non-low-income households, the probability of owning a cellular phone is positively correlated with age, and the probability of owning a landline phone is positively correlated with age, the value of the service, and the value of cellular service. These results suggest that among low-income households, respondents' status as lowincome is a defining characteristic. Our finding that a greater proportion of low-income 
households are choosing cellular over landline service supports this assertion. Additionally, it appears that among non-low-income households, the choice for cellular service is more complex, involving differences in characteristics other than income status.

Respondents who are presumed eligible for Lifeline are more likely to use only cellular phones than respondents presumed not eligible for Lifeline. From Table 7, 68 percent of presumed eligible respondents in the cellular phone survey have a cellular phone but no landline phone. This is significantly higher than for presumed non-eligible respondents, of which only 116 of 298 use cellular phones exclusively, or 38.9 percent. In contrast to the high percent of cellular-only presumed eligible respondents, in the landline survey, only 34 percent of the presumed eligible respondents reported having only a landline phone. ${ }^{27}$

Statistically, we find that those respondents in the lowest two income ranges $(\$ 0-\$ 9,999$ and $\$ 10,000$ - $\$ 19,999)$ have significantly higher average cellular-only ownership from other income groups. ${ }^{28}$ But while we are highly confident that persons in the lowest two income groups are more likely than persons in the higher income groups to have cellular service only, we cannot make similar claims about landline-only respondents. Differences in landline-only use among income groups are not statistically significant.

\footnotetext{
${ }^{27}$ The percentage of presumed eligible and presumed non-eligible respondents with only cellular phones is similar among intercept survey respondents, at 43.3 percent and 41.1 percent, respectively. However, the number of intercept survey respondents who are presumed non-eligible for Lifeline was small (17 out of 208 respondents), so it is difficult to place much confidence in the accuracy of the 41.1 percent statistic.

${ }^{28}$ In particular, the proportion of respondents in the two lowest income ranges who choose only cellular service is statistically higher than all higher income groups. The next highest income group differs from these two groups with a significance level of 0.7 percent.
} 
Table 7

Number of Respondents Choosing Each Mode of Communication by Presumed Eligibility and Survey Method, 2008

\begin{tabular}{|c|c|c|c|c|c|c|c|c|c|}
\hline \multirow{3}{*}{$\begin{array}{l}\text { Modes of } \\
\text { Communications }\end{array}$} & \multicolumn{3}{|c|}{ Landline Survey } & \multicolumn{3}{|c|}{ Cellular Survey } & \multicolumn{3}{|c|}{ Intercept Survey } \\
\hline & \multirow[b]{2}{*}{ All } & \multicolumn{2}{|c|}{$\begin{array}{c}\text { Presumed } \\
\text { Eligible? }\end{array}$} & \multirow[b]{2}{*}{ All } & \multicolumn{2}{|c|}{$\begin{array}{l}\text { Presumed } \\
\text { Eligible? }\end{array}$} & \multirow[b]{2}{*}{ All } & \multicolumn{2}{|c|}{$\begin{array}{l}\text { Presumed } \\
\text { Eligible? }\end{array}$} \\
\hline & & Yes & No & & Yes & No & & Yes & No \\
\hline Uses Landline & 489 & $\begin{array}{c}50 \\
100 \%\end{array}$ & $\begin{array}{l}307 \\
100 \%\end{array}$ & 268 & $\begin{array}{l}32 \\
32 \%\end{array}$ & $\begin{array}{l}182 \\
61 \%\end{array}$ & 98 & $\begin{array}{l}87 \\
47 \%\end{array}$ & $\begin{array}{c}9 \\
53 \%\end{array}$ \\
\hline Uses Cellular & 407 & $\begin{array}{l}33 \\
66 \%\end{array}$ & $\begin{array}{l}267 \\
87 \%\end{array}$ & 476 & $\begin{array}{l}100 \\
100 \%\end{array}$ & $\begin{array}{l}298 \\
100 \%\end{array}$ & 158 & $\begin{array}{l}139 \\
74 \%\end{array}$ & $\begin{array}{l}15 \\
88 \%\end{array}$ \\
\hline $\begin{array}{l}\text { Uses only } \\
\text { Landline }\end{array}$ & 80 & $\begin{array}{l}17 \\
34 \%\end{array}$ & $\begin{array}{l}39 \\
13 \%\end{array}$ & $\mathrm{n} / \mathrm{a}$ & $\mathrm{n} / \mathrm{a}$ & $\mathrm{n} / \mathrm{a}$ & 30 & $\begin{array}{l}29 \\
16 \%\end{array}$ & $\begin{array}{l}1 \\
6 \%\end{array}$ \\
\hline $\begin{array}{l}\text { Uses only } \\
\text { Cellular }\end{array}$ & $\mathrm{n} / \mathrm{a}$ & $\mathrm{n} / \mathrm{a}$ & $\mathrm{n} / \mathrm{a}$ & 208 & $\begin{array}{l}68 \\
68 \%\end{array}$ & $\begin{array}{l}116 \\
39 \%\end{array}$ & 90 & $\begin{array}{l}81 \\
43 \%\end{array}$ & $\begin{array}{c}7 \\
41 \%\end{array}$ \\
\hline $\begin{array}{l}\text { Uses Landline } \\
\text { and Cellular }\end{array}$ & 407 & $\begin{array}{l}33 \\
66 \%\end{array}$ & $\begin{array}{l}267 \\
87 \%\end{array}$ & 268 & $\begin{array}{l}32 \\
32 \%\end{array}$ & $\begin{array}{c}182 \\
61 \% \\
\end{array}$ & 68 & $\begin{array}{l}58 \\
31 \%\end{array}$ & $\begin{array}{c}8 \\
47 \% \\
\end{array}$ \\
\hline $\begin{array}{l}\text { Uses Neither } \\
\text { Landline nor } \\
\text { Cellular }\end{array}$ & $\mathrm{n} / \mathrm{a}$ & $\mathrm{n} / \mathrm{a}$ & $\mathrm{n} / \mathrm{a}$ & $\mathrm{n} / \mathrm{a}$ & $\mathrm{n} / \mathrm{a}$ & $\mathrm{n} / \mathrm{a}$ & 17 & $\begin{array}{l}17 \\
9 \%\end{array}$ & $\begin{array}{l}0 \\
0 \%\end{array}$ \\
\hline $\begin{array}{l}\text { Refused to } \\
\text { Answer* }\end{array}$ & 2 & $\begin{array}{l}0 \\
0 \% \\
\end{array}$ & $\begin{array}{l}1 \\
0.3 \% \\
\end{array}$ & $\begin{array}{l}0 \\
0 \% \\
\end{array}$ & $\begin{array}{l}0 \\
0 \% \\
\end{array}$ & $\begin{array}{l}0 \\
0 \% \\
\end{array}$ & 3 & $\begin{array}{l}2 \\
1 \% \\
\end{array}$ & $\begin{array}{l}1 \\
6 \% \\
\end{array}$ \\
\hline Total & 489 & 50 & 307 & 476 & 100 & 298 & 208 & 187 & 17 \\
\hline
\end{tabular}

Note: The "All" columns include respondents who did not report their income and, therefore, were not included in either the "presumed eligible" or "presumed non-eligible" calculations.

* For the landline survey, a refused answer indicates that the respondent did not answer whether he or she had a cellular phone. For the cellular survey, a refused answer indicates that the respondent did not answer whether he or she had a landline phone. For the intercept survey, a refused answer indicates that the respondent did not answer one or both of the questions pertaining to landline and cellular phone ownership.

In the previous PURC study, ${ }^{29}$ it was estimated that 90.4 percent of low-income households had a landline phone at home. Based on our intercept survey results, we find that only 46.5 percent of low-income households had a landline phone, and only 15.5 percent reported having only a landline phone. The prior PURC study was carried out differently than

${ }^{29}$ See Brown and Jamison (2005). 
our current study, but to the extent the statistics are comparable, they indicate a significant shift in cellular telephone usage among low-income households and could imply that landline phones are now becoming a luxury good, i.e., something that is purchased only when income permits or when purchased as part of a bundle, for example, with Internet DSL service. Also in contrast with the previous PURC study that found about 50 percent of low-income households had a cellular phone, our current study finds that about 70 percent have cellular phones; of landline survey respondents, 66 percent of the presumed eligible consumers have a cellular phone, while of intercept survey respondents, 76 percent of the presumed eligible consumers have a cellular phone.

\section{C. Choices of Service Providers}

In each survey, respondents were asked to identify which service provider they subscribe to for landline and/or cellular services. Table 8 shows these results. The majority of respondents in the phone surveys reported AT\&T as their local landline carrier, consistent with the relative sizes of the landline operators' territories in Florida. Almost all intercept survey respondents with

landline service reported AT\&T as their landline service provider, which is expected because the surveys were conducted in AT\&T service territories. 
Table 8

Number of Respondents by Service Provider and Survey Method, 2008

\begin{tabular}{|c|c|c|c|}
\hline \multirow[b]{2}{*}{ Service Provider } & \multicolumn{3}{|c|}{ Number of Respondents } \\
\hline & Landline Survey & Cellular Survey & Intercept Survey \\
\hline \multicolumn{4}{|l|}{ Landline Service } \\
\hline Alltel* & $\begin{array}{l}6 \\
1 \% \\
\end{array}$ & $\begin{array}{l}2 \\
0.7 \%\end{array}$ & $\begin{array}{l}2 \\
2 \% \\
\end{array}$ \\
\hline AT\&T/BellSouth & $\begin{array}{l}201 \\
41 \%\end{array}$ & $\begin{array}{c}133 \\
50 \%\end{array}$ & $\begin{array}{l}66 \\
67 \%\end{array}$ \\
\hline Embarq/Sprint & $\begin{array}{l}106 \\
22 \% \\
\end{array}$ & $\begin{array}{l}34 \\
13 \% \\
\end{array}$ & $\begin{array}{l}0 \\
0.0 \%\end{array}$ \\
\hline GTC & $\begin{array}{l}2 \\
0.4 \% \\
\end{array}$ & $\begin{array}{l}1 \\
0.4 \%\end{array}$ & $\begin{array}{l}0 \\
0.0 \%\end{array}$ \\
\hline Verizon & $\begin{array}{l}60 \\
12 \% \\
\end{array}$ & $\begin{array}{l}33 \\
12 \% \\
\end{array}$ & $\begin{array}{l}0 \\
0.0 \% \\
\end{array}$ \\
\hline Other $^{30}$ & $\begin{array}{l}89 \\
18 \% \\
\end{array}$ & $\begin{array}{l}59 \\
22 \%\end{array}$ & $\begin{array}{l}24 \\
24 \% \\
\end{array}$ \\
\hline Don't Know / No Answer & $\begin{array}{l}25 \\
5 \% \\
\end{array}$ & $\begin{array}{l}6 \\
2 \% \\
\end{array}$ & $\begin{array}{l}6 \\
6 \% \\
\end{array}$ \\
\hline Total & 489 & 268 & 98 \\
\hline \multicolumn{4}{|l|}{ Cellular Service Provider } \\
\hline Alltel & $\begin{array}{c}32 \\
7 \% \\
\end{array}$ & $\begin{array}{l}39 \\
8 \% \\
\end{array}$ & $\begin{array}{l}5 \\
8 \% \\
\end{array}$ \\
\hline AT\&T/Cingular & $\begin{array}{l}128 \\
30 \%\end{array}$ & $\begin{array}{c}182 \\
36 \%\end{array}$ & $\begin{array}{l}20 \\
12 \% \\
\end{array}$ \\
\hline Sprint/Nextel & $\begin{array}{l}49 \\
11 \% \\
\end{array}$ & $\begin{array}{l}43 \\
9 \% \\
\end{array}$ & $\begin{array}{l}9 \\
6 \% \\
\end{array}$ \\
\hline T-Mobile & $\begin{array}{l}58 \\
14 \%\end{array}$ & $\begin{array}{l}74 \\
15 \%\end{array}$ & $\begin{array}{l}28 \\
17 \%\end{array}$ \\
\hline Verizon & $\begin{array}{l}83 \\
19 \% \\
\end{array}$ & $\begin{array}{l}43 \\
9 \% \\
\end{array}$ & $\begin{array}{l}11 \\
7 \% \\
\end{array}$ \\
\hline Other & $\begin{array}{l}61 \\
14 \% \\
\end{array}$ & $\begin{array}{l}106 \\
21 \%\end{array}$ & $\begin{array}{l}88 \\
54 \% \\
\end{array}$ \\
\hline Don’t Know / No Answer & $\begin{array}{c}16 \\
4 \% \\
\end{array}$ & $\begin{array}{c}12 \\
2 \% \\
\end{array}$ & $\begin{array}{l}2 \\
1 \% \\
\end{array}$ \\
\hline Total & $427 * *$ & $499 * *$ & $163 * *$ \\
\hline
\end{tabular}

* Alltel no longer provides landline service in Florida.

** The total number of cell phone providers shown is greater than the number of respondents with cell phones. This is because some respondents reported multiple cell phones with different providers. Specifically, for the landline survey, of 407 respondents with cellular phones, 14 reported two providers, and 3 reported three providers. For the cellular survey, of 476 respondents, 21 reported two providers, and 1 reported three providers. For the intercept survey, of 161 respondents with cellular phones, 2 reported two providers.

${ }^{30}$ Other landline providers mentioned include Bright House (59), Comcast (37), Vonage (13), Cox (7), Supra (6), Windstream (6), FairPoint Communications (3), MCI (2), and Mediacom (2). No other landline operator was mentioned more than once. Other cellular providers mentioned include Metro PCS (145), Nextel (39), Track Phone (21), Boost (16), Clear Talk (8), and Virgin (7). No other cellular operator was mentioned more than once. 
The respondents who indicated Alltel as their landline provider were presumably unaware that Alltel had sold its landline properties. Of phone survey respondents, the majority indicated that AT\&T was their cellular service provider. T-Mobile and Other were the most prevalent responses of intercept survey respondents.

\section{D. Value of Communications Services}

One of the important questions relating to patterns of telecommunications usage among low-income households is how respondents estimate the value of the telecommunications service to them. Because income levels may influence value estimates, it is the respondent at the margin (where typical monthly bills slightly exceed value of service) for whom programs such as Lifeline should be most influential. In Table 9, we report the results from the survey questions about the value of landline and cellular services. Respondents were asked, "Regardless of what you actually pay for (this service) each month, how much is this service worth to you each month?" Table 9 indicates that of landline survey respondents, those presumed eligible, on average, value their landline telephone service nearly 60 percent more than presumed noneligible respondents. For cellular survey respondents this difference is over 50 percent. This may result from higher proportions of presumed eligible customers having only one type of phone, making this phone more valuable to them than to customers who have both landline and cellular phones. Also, presumed eligible respondents are shown to be more price sensitive, as indicated by the higher percentages of respondents who report that they would cancel their landline service or cellular service should their monthly bills rise. This probably reflects these respondents' lower income levels relative to the presumed non-eligible respondents. 
Table 9

Average Responses Regarding Monthly Bills, and Value of Landline and Cellular Services by Presumed Eligibility and Survey Method, 2008

\begin{tabular}{|c|c|c|c|c|c|c|c|c|c|}
\hline \multirow[b]{4}{*}{ Landline Service } & \multicolumn{9}{|c|}{ Average Responses } \\
\hline & \multicolumn{3}{|c|}{ Landline Survey } & \multicolumn{3}{|c|}{ Cellular Survey } & \multicolumn{3}{|c|}{ Intercept Survey } \\
\hline & \multirow[b]{2}{*}{ All } & \multicolumn{2}{|c|}{$\begin{array}{l}\text { Presumed } \\
\text { Eligible? }\end{array}$} & \multirow[b]{2}{*}{ All } & \multicolumn{2}{|c|}{$\begin{array}{l}\text { Presumed } \\
\text { Eligible? }\end{array}$} & \multirow[b]{2}{*}{ All } & \multicolumn{2}{|c|}{$\begin{array}{l}\text { Presumed } \\
\text { Eligible? }\end{array}$} \\
\hline & & Yes & No & & Yes & No & & Yes & No \\
\hline $\begin{array}{l}\text { Percent Would Cancel If Bill } \\
\text { Increased } \$ 10\end{array}$ & $36.3 \%$ & $58.1 \%$ & $35.6 \%$ & $37.8 \%$ & $46.7 \%$ & $34.7 \%$ & $54.3 \%$ & $56.6 \%$ & $22.2 \%$ \\
\hline $\begin{array}{l}\text { Percent Would Cancel If Bill } \\
\text { Increased } \$ 20\end{array}$ & $69.6 \%$ & $84.4 \%$ & $67.8 \%$ & $71.8 \%$ & $83.9 \%$ & $70.7 \%$ & $74.0 \%$ & $74.7 \%$ & $57.1 \%$ \\
\hline Value of Landline Service & $\$ 74.53$ & $\$ 109.86$ & $\$ 70.82$ & $\$ 63.86$ & $\$ 91.67$ & $\$ 60.54$ & $\$ 85.14$ & $\$ 83.15$ & $\$ 112.29$ \\
\hline \multicolumn{10}{|l|}{ Cellular Service } \\
\hline $\begin{array}{l}\text { Percent Would Cancel If Bill } \\
\text { Increased } \$ 10\end{array}$ & $21.9 \%$ & $52.2 \%$ & $18.9 \%$ & $24.7 \%$ & $28.9 \%$ & $22.5 \%$ & $36.1 \%$ & $39.3 \%$ & $15.4 \%$ \\
\hline $\begin{array}{l}\text { Percent Would Cancel If Bill } \\
\text { Increased } \$ 20\end{array}$ & $55.3 \%$ & $86.4 \%$ & $49.1 \%$ & $57.2 \%$ & $62.8 \%$ & $56.3 \%$ & $72.4 \%$ & $75.0 \%$ & $58.3 \%$ \\
\hline Value of Cellular Service & $\$ 104.91$ & $\$ 122.85$ & $\$ 108.68$ & $\$ 127.34$ & $\$ 120.88$ & $\$ 127.83$ & $\$ 129.22$ & $\$ 127.38$ & $\$ 155.94$ \\
\hline
\end{tabular}

Note: The "All" columns include respondents who did not report their income and, therefore, were not included in either the "presumed eligible" or "presumed non-eligible" calculations. 
Table 10

Average Responses Regarding Landline and Cellular Usage by Presumed Eligibility and Survey Method, 2008*

\begin{tabular}{|c|c|c|c|c|c|c|c|c|c|}
\hline \multirow[b]{4}{*}{ Category } & \multicolumn{9}{|c|}{ Average Responses } \\
\hline & \multicolumn{3}{|c|}{ Landline Survey } & \multicolumn{3}{|c|}{ Cellular Survey } & \multicolumn{3}{|c|}{ Intercept Survey } \\
\hline & \multirow[b]{2}{*}{ All } & \multicolumn{2}{|c|}{$\begin{array}{c}\text { Presumed } \\
\text { Eligible? }\end{array}$} & \multirow[b]{2}{*}{ All } & \multicolumn{2}{|c|}{$\begin{array}{c}\text { Presumed } \\
\text { Eligible? }\end{array}$} & \multirow[b]{2}{*}{ All } & \multicolumn{2}{|c|}{$\begin{array}{c}\text { Presumed } \\
\text { Eligible? }\end{array}$} \\
\hline & & Yes & No & & Yes & No & & Yes & No \\
\hline Percent of Total Calls Made on Cellular & $49.2 \%$ & $40.4 \%$ & $53.2 \%$ & $63.8 \%$ & $56.8 \%$ & $66.1 \%$ & $58.9 \%$ & $56.6 \%$ & $65.9 \%$ \\
\hline Percent of Long Distance Made on Cellular & $44.7 \%$ & $25.0 \%$ & $48.9 \%$ & $51.4 \%$ & $41.1 \%$ & $52.1 \%$ & $46.1 \%$ & $41.8 \%$ & $76.3 \%$ \\
\hline Percent Using Prepaid Cellular & $15.3 \%$ & $30.0 \%$ & $15.2 \%$ & $6.4 \%$ & $13.3 \%$ & $5.1 \%$ & $22.6 \%$ & $23.0 \%$ & $18.8 \%$ \\
\hline
\end{tabular}

* Table 10 includes only those respondents with both a landline and a cellular phone. 
When compared with the previous PURC studies, ${ }^{31}$ Table 10 indicates that the penetration of prepaid cellular phones has about doubled for low-income households in the past three years. According to the 2005 survey of low-income households (Brown, 2006c), 11.3 percent indicated that they had a personal pre-paid cellular phone. In contrast, in our 2008 landline, cellular, and intercept surveys, respectively 30 percent, 13.3 percent, and 23 percent of the respondents presumed to be eligible for Lifeline indicated that they use prepaid cellular phones.

We now turn to the summary of cellular phone services reported in Table 10. The data indicate that Floridians whom we presume do not qualify for Lifeline make larger proportions of their calls using cellular phones than landline phones, relative to Floridians whom we presume to be eligible for Lifeline. We also asked survey respondents with cellular phones to report whether they use a prepaid cellular plan or receive a monthly bill. Table 10 shows that low-income households (those who are presumed eligible for the Lifeline program) are more likely to use prepaid cellular calling plans than presumed non-eligible households. ${ }^{32}$ This preference would imply that Lifeline discounts might be more beneficial to low-income households if applied to prepaid cellular phones than to landline or postpaid cellular phones.

Comparing the survey results in Tables 9 and 10 with the previous PURC telephone surveys (Brown, 2006a), we see the possibility of an increasing tendency for consumers to use cellular phones for their calls. ${ }^{33}$ In 2005 , about 25 percent of the respondents used their cellular phones for most of their calls. Table 10 above shows that consumers are now making on average half or more of their calls on cellular phones. Also, the 2005 survey showed that consumers

\footnotetext{
${ }^{31}$ See Holt and Jamison (2006, 2007), Brown and Jamison (2005), and Brown (2006a, 2006b, 2006c).

${ }^{32}$ Of landline survey respondents, prepaid is twice as likely; of cellular survey respondents, prepaid is two and a half times as likely; of intercept survey respondents, prepaid is 30 percent more likely.

${ }^{33}$ The questions in 2005 are not directly comparable to those asked in 2008.
} 
tended to indicate that their landline phones were more valuable to them than their cellular phones: 42.7 percent indicated that their landline phones were their most valuable communications purchase, while 26.5 percent indicated that their cellular phone was their most valuable communications purchase. Those indicating in 2005 that cellular was their most valuable purchase tended to be more affluent than those valuing landline phones. Table 9 above shows that in 2008, consumers on average view their cellular phones as more valuable than their landline phones and that the pattern holds even for consumers whom we classify as presumed eligible for Lifeline. These patterns indicate an increasing tendency for consumers to see cellular as their normal and preferred mode of communications, regardless of income level.

An analysis of the respondents who use prepaid cellular calling plans shows that the reasons for choosing a prepaid cellular plan are diverse, but that the ability to control phone costs is the primary motivation for using prepaid cellular, especially in the intercept survey in which there was a higher proportion of low-income households than in the other surveys. Respondents were requested to select as many of the criteria listed in Table 11 below as applied. This finding provides what may be an important insight when compared with the findings of the PURC studies conducted in 2005. The earlier studies concluded that low-income households discontinued landline service because it was either unaffordable or the household preferred to spend its income on other things. Prepaid cellular phones provide low-income households an opportunity to manage their communications expenditures, and so may be more suitable than a landline phone to a low-income household's lifestyle. 
Table 11

Reasons for Subscribing to Prepaid Cellular by Survey Method, 2008

\begin{tabular}{|l|c|c|c|}
\hline \multirow{2}{*}{ Reasons for Using Prepaid } & \multicolumn{3}{|c|}{ Numbers and Percentages of Respondents } \\
\cline { 2 - 4 } & Landline Survey & Cellular Survey & Intercept Survey \\
\hline \multirow{2}{*}{ No monthly bill } & 22 & 12 & 21 \\
& $37 \%$ & $40 \%$ & $58 \%$ \\
\hline \multirow{2}{*}{ Do not use cell phone much } & 33 & 5 & 9 \\
& $55 \%$ & $17 \%$ & $25 \%$ \\
\hline \multirow{2}{*}{ No credit check required } & 5 & 10 & 12 \\
& $8 \%$ & $33 \%$ & $33 \%$ \\
\hline \multirow{2}{*}{ To save money } & 23 & 15 & 15 \\
& $38 \%$ & $50 \%$ & $42 \%$ \\
\hline \multirow{2}{*}{ To predict expenses } & 17 & 15 & 15 \\
& $28 \%$ & $50 \%$ & $42 \%$ \\
\hline \multirow{2}{*}{ Other reasons } & 28 & 13 & 8 \\
& $47 \%$ & $43 \%$ & $22 \%$ \\
\hline \multirow{2}{*}{ Total Respondents } & $\mathbf{6 0}$ & $\mathbf{3 0}$ & $\mathbf{3 6}$ \\
\hline
\end{tabular}

We next turn our attention to the increasing number of respondents who choose not to subscribe to a landline service. In Table 12, we summarize the reasons for non-subscription indicated by respondents. Additionally, we include respondents' reported willingness-to-pay for landline service as an indicator of its value. Finally, we include whether the respondent reported having landline service at some point within the last five years in order to estimate the extent to which respondents may have canceled landline service as opposed to never having received it.

Table 12 indicates that first, presumed eligible respondents reportedly are more willing to pay for a landline phone than are presumed non-eligible respondents. Second, presumed eligible respondents are more likely not to have a landline phone due to a recent move, perhaps suggesting that lower-income households relocate more frequently than higher-income households. A possible implication for Lifeline policy is that a cellular phone might be more suitable for many low-income households than a landline phone. 
Table 12

Reasons for Not Subscribing to Landline Service and Percentage of Respondents with Landline Service within the Past Five Years, by Presumed Eligibility and Survey Method, 2008

\begin{tabular}{|c|c|c|c|c|c|c|}
\hline \multirow[b]{4}{*}{ Category } & \multicolumn{6}{|c|}{ Respondents } \\
\hline & \multicolumn{3}{|c|}{ Cellular Survey } & \multicolumn{3}{|c|}{ Intercept Survey } \\
\hline & \multirow[b]{2}{*}{ All } & \multicolumn{2}{|c|}{ Presumed Eligible? } & \multirow[b]{2}{*}{ All } & \multicolumn{2}{|c|}{ Presumed Eligible? } \\
\hline & & Yes & No & & Yes & No \\
\hline $\begin{array}{l}\text { Respondents with no } \\
\text { Landline }\end{array}$ & $\begin{array}{l}208 \\
43.7 \% \\
\end{array}$ & $\begin{array}{l}68 \\
68.0 \% \\
\end{array}$ & $\begin{array}{l}116 \\
38.9 \% \\
\end{array}$ & $\begin{array}{l}110 \\
52.9 \% \\
\end{array}$ & $\begin{array}{l}100 \\
53.5 \% \\
\end{array}$ & $\begin{array}{c}8 \\
47.1 \% \\
\end{array}$ \\
\hline $\begin{array}{l}\text { Willingness-to-pay } \\
\text { for Landline }\end{array}$ & $\$ 23.40$ & $\$ 31.58$ & $\$ 18.21$ & $\$ 30.73$ & $\$ 31.60$ & $\$ 25.63$ \\
\hline $\begin{array}{l}\text { Percent with } \\
\text { Landline in past } 5 \\
\text { years }\end{array}$ & $60.9 \%$ & $58.2 \%$ & $63.8 \%$ & $63.6 \%$ & $63.0 \%$ & $62.5 \%$ \\
\hline \multicolumn{7}{|c|}{ Reasons for No Landline Phone } \\
\hline Too expensive & 51 & 14 & 30 & 47 & 44 & 2 \\
\hline Do not need & 96 & 26 & 60 & 10 & 9 & 1 \\
\hline Do not want & 65 & 16 & 41 & 10 & 8 & 2 \\
\hline Have cell phone & 117 & 37 & 69 & 54 & 51 & 3 \\
\hline $\begin{array}{l}\text { Changed to } \\
\text { Broadband }\end{array}$ & 32 & 11 & 18 & 1 & 1 & 0 \\
\hline Recently moved & 35 & 16 & 16 & 14 & 13 & 1 \\
\hline Move too frequently & 17 & 9 & 8 & 6 & 6 & 0 \\
\hline Other & 40 & 12 & 22 & 12 & 10 & 1 \\
\hline
\end{tabular}

Note: The "All" columns include respondents who did not report their income and, therefore, were not included in either the "presumed eligible" or "presumed non-eligible" calculations.

We conclude this section of this report by providing survey results from the questions relating directly to the Lifeline program. Specifically, each survey asks respondents about their awareness of the Lifeline program, whether they subscribe to Lifeline, and whether they would sign up if eligible for the program. Table 13 summarizes the data from these questions. 
Table 13

Average Percentages of Persons Indicating Knowledge of and Perceived Value of Lifeline by Survey Method, 2008

\begin{tabular}{|c|c|c|c|c|c|c|c|c|c|}
\hline \multirow[b]{4}{*}{ Category } & \multicolumn{9}{|c|}{ Percents of Respondents } \\
\hline & \multicolumn{3}{|c|}{ Landline Survey } & \multicolumn{3}{|c|}{ Cellular Survey } & \multicolumn{3}{|c|}{ Intercept Survey } \\
\hline & \multirow[b]{2}{*}{ All } & \multicolumn{2}{|c|}{$\begin{array}{l}\text { Presumed } \\
\text { Eligible? }\end{array}$} & \multirow[b]{2}{*}{ All } & \multicolumn{2}{|c|}{$\begin{array}{c}\text { Presumed } \\
\text { Eligible? }\end{array}$} & \multirow[b]{2}{*}{ All } & \multicolumn{2}{|c|}{$\begin{array}{c}\text { Presumed } \\
\text { Eligible? }\end{array}$} \\
\hline & & Yes & No & & Yes & No & & Yes & No \\
\hline $\begin{array}{l}\text { Percent Aware of } \\
\text { Lifeline }\end{array}$ & $18.2 \%$ & $20.0 \%$ & $18.2 \%$ & $17.7 \%$ & $23.2 \%$ & $15.1 \%$ & $50.5 \%$ & $50.3 \%$ & $64.7 \%$ \\
\hline $\begin{array}{l}\text { Percent Subscribe } \\
\text { to Lifeline }\end{array}$ & $1.7 \%$ & $10.2 \%$ & $\mathrm{n} / \mathrm{a}$ & $2.1 \%$ & $4.1 \%$ & $\mathrm{n} / \mathrm{a}$ & $18.4 \%$ & $19.9 \%$ & $\mathrm{n} / \mathrm{a}$ \\
\hline $\begin{array}{l}\text { Percent of Aware } \\
\text { that Subscribe }\end{array}$ & $8.2 \%$ & $50.0 \%$ & $\mathrm{n} / \mathrm{a}$ & $11.9 \%$ & $17.4 \%$ & $\mathrm{n} / \mathrm{a}$ & $36.5 \%$ & $39.8 \%$ & $\mathrm{n} / \mathrm{a}$ \\
\hline $\begin{array}{l}\text { Percent Requested } \\
\text { Information }\end{array}$ & $35.5 \%$ & $71.1 \%$ & $38.2 \%$ & $36.9 \%$ & $56.3 \%$ & $34.5 \%$ & $\mathrm{n} / \mathrm{a}$ & $\mathrm{n} / \mathrm{a}$ & $\mathrm{n} / \mathrm{a}$ \\
\hline $\begin{array}{l}\text { Percent Would Sign } \\
\text { Up If Eligible }\end{array}$ & $57.3 \%$ & $66.7 \%$ & $61.8 \%$ & $53.2 \%$ & $66.0 \%$ & $49.8 \%$ & $79.8 \%$ & $81.1 \%$ & $62.5 \%$ \\
\hline $\begin{array}{l}\text { Percent Saw Option } \\
\text { to Sign Up }\end{array}$ & $\mathrm{n} / \mathrm{a}$ & $\mathrm{n} / \mathrm{a}$ & $\mathrm{n} / \mathrm{a}$ & $\mathrm{n} / \mathrm{a}$ & $\mathrm{n} / \mathrm{a}$ & $\mathrm{n} / \mathrm{a}$ & $45.2 \%$ & $50.0 \%$ & $\mathrm{n} / \mathrm{a}$ \\
\hline $\begin{array}{l}\text { Percent Signed Up } \\
\text { at DCF Office }\end{array}$ & $\mathrm{n} / \mathrm{a}$ & $\mathrm{n} / \mathrm{a}$ & $\mathrm{n} / \mathrm{a}$ & $\mathrm{n} / \mathrm{a}$ & $\mathrm{n} / \mathrm{a}$ & $\mathrm{n} / \mathrm{a}$ & $8.7 \%$ & $9.6 \%$ & $\mathrm{n} / \mathrm{a}$ \\
\hline
\end{tabular}

Note: The "All" columns include respondents who did not report their income and, therefore, were not included in either the "presumed eligible" or "presumed non-eligible" calculations. 
Based on Table 13, we find that among presumed eligible respondents to Lifeline, only 10.2 percent of landline survey respondents, 4.1 percent of cellular survey respondents, and 19.9 percent of intercept survey respondents subscribe to Lifeline, a lower subscription rate than found in earlier studies. ${ }^{34}$ This may be influenced by what appears to be a growing number of low-income households relying only on cellular services. Yet, based on the data, awareness of the Lifeline program remains an important factor: based on the three surveys, 20.0 percent, 23.2 percent, and 50.3 percent of Lifeline eligible respondents in the landline, cellular, and intercept surveys are aware of the program, respectively. Among the respondents who are aware of the program, the subscription rate for landline, cellular, and intercept surveys is significantly higher at 50.0 percent, 17.4 percent, and 39.8 percent, respectively. Detailed information on the reasons respondents do not subscribe is presented in Table 14.

Of interest is the relatively large number of respondents who do not have a landline phone so are in some situations unable to subscribe to Lifeline. Also of interest is the total number of respondents who reportedly do not subscribe due to some degree of difficulty associated with subscribing; 22 of 66 respondents, or approximately one-third of all respondents to this question fall into this category.

\footnotetext{
${ }^{34}$ See Brown and Jamison (2005) and Brown (2006a, 2006b, 2006c).
} 
Table 14

Reported Reasons Respondents Aware of Lifeline Do Not Subscribe, 2008*

\begin{tabular}{|l|c|c|}
\hline \multicolumn{1}{|c|}{ Reported Reason } & $\begin{array}{c}\text { Total Number } \\
\text { of Respondents }\end{array}$ & $\begin{array}{c}\text { Percentage of } \\
\text { Respondents }\end{array}$ \\
\hline Did not know about the program** & 9 & $13.6 \%$ \\
\hline Too confusing & 8 & $12.1 \%$ \\
\hline Too much effort to subscribe & 6 & $9.0 \%$ \\
\hline Do not qualify for the program & 6 & $9.0 \%$ \\
\hline Uneasy about the process & 6 & $9.0 \%$ \\
\hline Other*** & 36 & $54.5 \%$ \\
\hline No landline phone & 11 & $16.7 \%$ \\
\hline Don't need it & 4 & $6.0 \%$ \\
\hline Have Comcast & 3 & $4.5 \%$ \\
\hline Believe they are ineligible & 2 & $3 \%$ \\
\hline Use cell phone mostly & 2 & $3 \%$ \\
\hline Waiting for qualification & 2 & $3 \%$ \\
\hline
\end{tabular}

* Respondents were asked, "Are you aware of the Lifeline Telephone Assistance Program that provides money to help qualifying households pay their home telephone bills?" If the respondent answered "yes," the following question was asked, "Do you subscribe to the Lifeline program?" For those respondents answering "no," the surveyor then asked, "Why do you not subscribe to the Lifeline program?" This table presents respondents' answers to the final question.

** Respondents indicating they are aware of the program were given the option of saying they did not know about the program; 9 of 66 persons did so.

*** Reasons listed are those that more than one respondent cited. Other reasons of potential relevance because they suggest confusion about the program include: "I have a phone," "I can't afford it," "Computer wouldn't do it," and "Don't take the company."

Respondents who used a computer at the DCF office to enroll in any welfare program were asked a similar question to those above. Specifically, we asked, "Did you select the option to allow DCF to release your name, social security number, and phone number to the local telephone company so you might receive a reduced rate through the Lifeline program?" The question mirrors the question respondents would see on the computer screen; our interest in asking the question in this form was in determining whether the presentation on that screen in any way deters subscription. Table 15 summarizes the reasons of those respondents who did not select the option to allow DCF to release the required information. 
Table 15

Reported Reasons Respondents Did Not Select the Option to Subscribe to Lifeline through DCF, 2008

\begin{tabular}{|l|c|c|}
\hline \multicolumn{1}{|c|}{ Reported Reason } & $\begin{array}{c}\text { Total Number of } \\
\text { Respondents }\end{array}$ & $\begin{array}{c}\text { Percentage of } \\
\text { Respondents }\end{array}$ \\
\hline Unsure what program is about & 11 & $22.4 \%$ \\
\hline Concerned about confidentiality & 4 & $8.2 \%$ \\
\hline Uncomfortable releasing SSN & 2 & $4.1 \%$ \\
\hline Uncomfortable providing phone number & 1 & $2.0 \%$ \\
\hline Other* & 41 & $83.7 \%$ \\
\hline No current phone in the household & 11 & $22.4 \%$ \\
\hline Phone in someone else's name & 5 & $10.2 \%$ \\
\hline Don't want home phone & 3 & $6.1 \%$ \\
\hline Prefer a cell phone & 3 & $6.1 \%$ \\
\hline Already get Lifeline & 2 & $4.1 \%$ \\
\hline Don't have Comcast as a provider & 2 & $4.1 \%$ \\
\hline Don't think I'm eligible & 2 & $4.1 \%$ \\
\hline Already have a phone & 2 & $4.1 \%$ \\
\hline
\end{tabular}

*Answers provided by only one respondent are not reported ( 8 total). Of possible interest among those answers are the following: "Didn't know what it was," "Didn't want Lifeline," "Just missed it," and "Always a catch so I never select anything."

Separating those respondents who appear not to subscribe because they have concerns about the program from those who do not subscribe for other reasons, we find that the majority ( 29 of 40 or 72.5 percent) do not subscribe for what might be deemed "logical" reasons, such as they do not have a phone. ${ }^{35}$ Such reasons cannot readily be addressed through changes of the subscription process. For example, not having or not wanting a landline phone accounts for 76 percent of those who appear to understand the program and choose not to subscribe.

Another question asked of non-Lifeline subscribers in each survey was the amount of subsidy that would induce the respondent to sign up for Lifeline. Interestingly, for all three

\footnotetext{
35 "Logical" reasons include the following: no phone in home or in person's name, don't want a home phone, prefer a cell phone, already get Lifeline, don't think I'm eligible, don't want Lifeline, may move soon, and have cable Internet rather than phone. Reasons suggesting possible misunderstanding of the program include the following: already have a phone, don't have Comcast as a provider, always a catch, didn't know what it was, don't care, thought I needed proof, and I only have one phone line. One person is not classified in the above with the response "just missed it."
} 
surveys, the required subsidy among presumed eligible respondents was higher than the required subsidy to encourage presumed non-eligible respondents to subscribe. In other words, those who are eligible to receive the subsidy actually are less willing to sign up compared to those who are not eligible for the program. We find that among the lowest two income ranges, being younger, female, and less educated are significantly correlated with requiring a higher incentive in order to sign up for Lifeline. At income levels greater than the lowest two, this result reverses: being older and male is associated with requiring a higher incentive in order to sign up for Lifeline. It is difficult to understand why this might be true, but this finding is consistent with the low percentage (19.9 percent) of presumed eligible respondents exiting a DCF office who actually signed up for Lifeline.

\section{Conclusion}

This study was undertaken to better understand how enrollment procedures impact households' participation in Lifeline, what eligible households understand from enrollment efforts, how low-income household use of wireless communications impacts enrollment in Lifeline, and what communications services low-income households and consumers in Florida are purchasing and/or using. We find that low participation rates appear to be influenced by changing patterns in modes of communications and lack of awareness of Lifeline. Our research indicates that low-income households are migrating quickly from landline phones - which have been the focus of Lifeline efforts - to cellular phones, which only recently are becoming eligible

for Lifeline discounts. In general, respondents to our landline survey had higher incomes and were older than the respondents to our cellular and intercept surveys. Of the survey respondents reached by a means other than a landline phone, only about one-half had a landline phone, but of 
those reached by a means other than a cellular phone, over three-fourths had a cellular phone. This would imply that cellular phones are becoming the preferred mode of voice communications.

Our data also reflect a growing trend in that those who subscribe only to one form of communication (landline or cellular phone) are increasingly choosing a cellular phone, and this is more pronounced for low-income households than for higher income households. This shift in cellular telephone usage among low-income households could imply that landline phones are now becoming a luxury good.

Compared with previous PURC studies, our current study indicates that the penetration of prepaid cellular phones has about doubled for low-income households in the past three years, apparently because prepaid cellular phones make it easier for low-income households to manage their telecommunications expenditures.

Our research implies some possible avenues for improving the current Lifeline program.

- Decrease the emphasis on landline service and increase the opportunities for eligible households to obtain discounts on prepaid cellular phones. Cellular phones, in particular prepaid cellular phones, are becoming the communications mode of choice for low-income households. As was found in the initial PURC studies (2005), the focus on landline phones could be an impediment to low-income households' adoption of more advanced telecommunications technologies.

- Reexamine whether price discounts are an important feature for Lifeline. Prices do not appear to be a primary barrier to low-income households' use of telecommunications services. Frequency of moving for low-income households appears to be one of the major 
impediments to having a phone. An emphasis on helping low-income households obtain cellular phones might be more effective than price discounts, especially price discounts on landline phones.

- To the extent that price discounts remain a feature of outreach to low-income households, consider a program design that does not favor one technology over another. For example, a program that provides a technology-neutral communications stamp could allow low-income households to easily migrate to VoIP, broadband, or other new technologies.

- Simplify participation procedures. The processes for learning about Lifeline, determining eligibility, and signing up remain a hindrance. In lieu of less targeted marketing approaches, perhaps outreach events and DCF offices could distribute cards for prepaid wireless phones or could provide prepaid phones at a discount. Perhaps Lifeline wireless prepaid minutes could be sold at common retail outlets such as WalMart, where a person could qualify to purchase such minutes in the same way he or she currently uses food stamps or prescription drug discounts. 


\section{References}

Andrade, Carlos, and Faculdade de Ciencias Economicas e Empresariais. 2002. "The Economics of Welfare Participation and Welfare Stigma: A Review." Public Finance and Management 2(2): 294-333.

Brown, Justin, and Mark A. Jamison. 2005. "Motivations Behind Low-Income Households Bypass of Support for Universal Service." University of Florida, Department of Economics, PURC Working Paper.

Brown, Justin. 2006a. "Disconnecting from Communications: A Survey of Floridians Who Qualify for Lifeline and Dropped Their Telephone Service." University of Florida, Department of Telecommunication, PURC Working Paper.

Brown, Justin. 2006b. "Perspectives on Communications Services and Lifeline: Results of a Telephone Survey of Florida Households." University of Florida, Department of Telecommunication, PURC Working Paper.

Brown, Justin. 2006c. "Understanding Participation in Telecommunications Lifeline Programs: A Survey of Low-Income Households in Florida." University of Florida, Department of Telecommunication, PURC Working Paper.

Burton, Mark, Jeffrey Macher, and John W. Mayo. 2007. "Understanding Participation in Social Programs: Why Don't Households Pick up the Lifeline?" The B.E. Journal of Economic Analysis and Policy 7(1): 1-26.

Currie, Janet. 2004. "The Take Up of Social Benefits.” National Bureau of Economic Research Working Paper 10488, Cambridge, MA.

Eriksson, Ross C., David L. Kaserman, and John W. Mayo. 1998. "Targeted and Untargeted Subsidy Schemes: Evidence from Postdivestiture Efforts to Promote Universal Telephone Service." Journal of Law and Economics 41(2): 477-502.

Florida Public Service Commission. 2007. "Report to the Governor, President of the Senate, Speaker of the House of Representatives: Link-Up Florida and Lifeline Assistance Report."

Garbacz, Christopher, and Herbert G. Thompson, Jr. 1997. "Assessing the Impact of FCC Lifeline and Linkup Programs on Telephone Penetration." Journal of Regulatory Economics, 11 (1): $67-78$.

Garbacz, Christopher, and Herbert G. Thompson, Jr. 2002. "Estimating Telephone Demand with State Decennial Census Data from 1970 - 1990.” Journal of Regulatory Economics, 21(3): 317 329. 
Garbacz, Christopher, and Herbert G. Thompson, Jr. 2003. "Estimating Telephone Demand with State Decennial Census Data from 1970 - 1990: Update with 2000 Data." Journal of Regulatory Economics, 24(3): 373-378.

Hauge, Janice A., and Mark A. Jamison. Forthcoming. "Effects of Using Specific versus General Data in Social Program Research.” Applied Economics.

Hauge, Janice A., Mark A. Jamison, and R. Todd Jewell. 2007. "Participation in Social Programs by Consumers and Companies: A Nationwide Analysis of Participation Rates for Telephone Lifeline Programs." Public Finance Review, 35(5): 606 - 625.

Hauge, Janice A., Mark A. Jamison, and R. Todd Jewell. Forthcoming. "Discounting Telephone Service: An Examination of Participation in the Lifeline Assistance Program Using Panel Data." Information Economics and Policy.

Holt, Lynne, and Mark A. Jamison. 2006. "Making Telephone Service Affordable for LowIncome Households: An Analysis of Lifeline and Link-Up Telephone Programs in Florida." University of Florida, Department of Economics, PURC Working Paper.

Holt, Lynne, and Mark A. Jamison. 2007. "Re-evaluating FCC Policies Concerning the Lifeline and Link-Up Programs." Journal on Telecommunications and High Technology Law, 5(2): 393412.

Hox, Joop A., and Edith D. De Leeuw. 1994. "A Comparison of Nonresponse in Mail, Telephone, and Face-to-Face Surveys.” Quality and Quantity, 28(4): 329-344.

Moffitt, Robert. 1983. "An Economic Model of Welfare Stigma." American Economic Review, 73(5): 1023-1035.

Pew Research Center. 2008. "Ways of Coping with a Growing Population Segment: The Impact of "Cell-Onlys" on Public Opinion Polling."

Rodini, Mark, Michael R. Ward, and Glenn A. Woroch. 2003. "Going Mobile: Substitutability Between Fixed and Mobile Access.” Telecommunications Policy, 27(5-6): 457-476.

Rosston, Gregory L., and Bradley S. Wimmer. 2000. "The 'State' of Universal Service." Information Economics and Policy, 12(3): 261-283.

Valletti, Tommaso M., Steffan Hoernig, and Pedro P. Barros. 2002. "Universal Service and Entry: The Role of Uniform Pricing and Coverage Constraints." Journal of Regulatory Economics, 21(2): 169-190.

Williamson, Anne. 2006. A Count of the Number of Households in Florida that Qualify for Lifeline Telephone Discounts, 2000 to 2005. Shimberg Center for Affordable Housing, University of Florida; available at http://www.purc.ufl.edu. 


\section{Appendix A: Response Rates for Individual Survey Questions}

The three survey samples, which constitute the primary source of data for this report, were completed by randomly selected respondents on a strictly voluntary basis. Some respondents occasionally chose not to answer a particular question posed from the survey. Subsequently, the number of responses for each question varies in each of the surveys. Because the summary statistics of a number of key variables were presented in percentages in the tables, it is sometimes helpful to know the actual number of respondents to which those percentages apply. Table A1 lists the number of responses for selected questions of primary importance along with the total respondents to whom that question was posed. The ratio between these two numbers represents the response rate for each respective question, shown as a percentage beneath each ratio.

The data in Table A1 shows that response rates in general are highest for the intercept survey and lowest for the landline surveys. This finding is consistent with research by Hox and De Leeuw (1994), which showed in an analysis of 45 separate studies on response rates among mail, telephone, and intercept surveys that intercept surveys achieved higher average response rates than phone surveys. While the response rates for each individual question are fairly consistent in their differences between survey methods, a significant difference in response rate appears for reported household income, with $93.8 \%$ of intercept respondents reporting their income and only $73.0 \%$ of landline respondents reporting. Possible causes of this difference may be the large differences in average age, gender, and incomes among the samples. 
Table A1

Number of Responses and Total Respondents Asked by Question and by Survey Method, 2008

\begin{tabular}{|c|c|c|c|}
\hline Question & $\begin{array}{l}\text { Landline } \\
\text { Survey }\end{array}$ & $\begin{array}{l}\text { Cellular } \\
\text { Survey }\end{array}$ & $\begin{array}{c}\text { Intercept } \\
\text { Survey }\end{array}$ \\
\hline Gender & $\begin{array}{c}488 / 489 \\
99.8 \% \\
\end{array}$ & $\begin{array}{c}476 / 476 \\
100 \% \\
\end{array}$ & $\begin{array}{c}208 / 208 \\
100 \%\end{array}$ \\
\hline Age & $\begin{array}{c}471 / 489 \\
96.3 \%\end{array}$ & $\begin{array}{c}467 / 476 \\
98.1 \%\end{array}$ & $\begin{array}{c}206 / 208 \\
99.0 \%\end{array}$ \\
\hline Own or Rent Residence & $\begin{array}{c}475 / 489 \\
97.1 \% \\
\end{array}$ & $\begin{array}{c}469 / 476 \\
98.5 \%\end{array}$ & $\begin{array}{c}202 / 208 \\
97.1 \% \\
\end{array}$ \\
\hline $\begin{array}{l}\text { Total Number of Persons in } \\
\text { Household }\end{array}$ & $\begin{array}{c}477 / 489 \\
97.5 \% \\
\end{array}$ & $\begin{array}{c}475 / 476 \\
99.8 \%\end{array}$ & $\begin{array}{c}207 / 208 \\
99.5 \%\end{array}$ \\
\hline $\begin{array}{l}\text { No. of Children under Age } 18 \text { in } \\
\text { Household }\end{array}$ & $\begin{array}{c}474 / 489 \\
96.9 \%\end{array}$ & $\begin{array}{c}469 / 476 \\
98.5 \%\end{array}$ & $\begin{array}{c}207 / 208 \\
99.5 \%\end{array}$ \\
\hline Household Income & $\begin{array}{c}357 / 489 \\
73.0 \% \\
\end{array}$ & $\begin{array}{c}398 / 476 \\
83.6 \%\end{array}$ & $\begin{array}{l}195 / 208 \\
93.8 \%\end{array}$ \\
\hline Estimated Landline Monthly Bill & $\begin{array}{c}405 / 489 \\
82.8 \% \\
\end{array}$ & $\begin{array}{c}236 / 268 \\
88.1 \% \\
\end{array}$ & $\begin{array}{l}93 / 98 \\
94.9 \% \\
\end{array}$ \\
\hline $\begin{array}{l}\text { Would Cancel If Landline Bill } \\
\text { Increased } \$ 10\end{array}$ & $\begin{array}{c}443 / 489 \\
90.6 \% \\
\end{array}$ & $\begin{array}{c}249 / 268 \\
92.5 \% \\
\end{array}$ & $\begin{array}{l}94 / 98 \\
95.9 \% \\
\end{array}$ \\
\hline $\begin{array}{l}\text { Would Cancel If Landline Bill } \\
\text { Increased \$20 }\end{array}$ & $\begin{array}{c}444 / 489 \\
90.8 \% \\
\end{array}$ & $\begin{array}{c}252 / 268 \\
94.0 \% \\
\end{array}$ & $\begin{array}{l}96 / 98 \\
98.0 \% \\
\end{array}$ \\
\hline Value of Landline Service & $\begin{array}{c}377 / 489 \\
77.1 \% \\
\end{array}$ & $\begin{array}{c}226 / 268 \\
84.3 \% \\
\end{array}$ & $\begin{array}{l}91 / 98 \\
92.9 \%\end{array}$ \\
\hline Estimated Cellular Monthly Bill & $\begin{array}{c}300 / 331 \\
90.6 \% \\
\end{array}$ & $\begin{array}{c}421 / 438 \\
96.1 \%\end{array}$ & $\begin{array}{c}120 / 122 \\
98.4 \% \\
\end{array}$ \\
\hline $\begin{array}{l}\text { Would Cancel If Cellular Bill } \\
\text { Increased } \$ 10\end{array}$ & $\begin{array}{c}322 / 331 \\
97.3 \% \\
\end{array}$ & $\begin{array}{c}424 / 438 \\
96.8 \%\end{array}$ & $\begin{array}{c}120 / 122 \\
98.4 \%\end{array}$ \\
\hline $\begin{array}{l}\text { Would Cancel If Cellular Bill } \\
\text { Increased } \$ 20\end{array}$ & $\begin{array}{c}320 / 331 \\
96.7 \% \\
\end{array}$ & $\begin{array}{c}427 / 438 \\
97.5 \% \\
\end{array}$ & $\begin{array}{c}121 / 122 \\
99.2 \% \\
\end{array}$ \\
\hline Value of Cellular Service & $\begin{array}{c}332 / 407 \\
81.6 \%\end{array}$ & $\begin{array}{c}419 / 476 \\
88.0 \%\end{array}$ & $\begin{array}{l}151 / 158 \\
95.6 \%\end{array}$ \\
\hline Total Usage by Cellular Phone & $\begin{array}{c}370 / 407 \\
90.1 \% \\
\end{array}$ & $\begin{array}{c}445 / 476 \\
93.5 \% \\
\end{array}$ & $\begin{array}{c}148 / 158 \\
93.7 \%\end{array}$ \\
\hline $\begin{array}{l}\text { Total Long Distance Usage by } \\
\text { Cellular Phone }\end{array}$ & $\begin{array}{c}389 / 407 \\
95.6 \%\end{array}$ & $\begin{array}{c}460 / 476 \\
96.6 \%\end{array}$ & $\begin{array}{c}155 / 158 \\
98.1 \% \\
\end{array}$ \\
\hline Prepaid Cellular Service & $\begin{array}{c}391 / 407 \\
96.1 \% \\
\end{array}$ & $\begin{array}{c}468 / 476 \\
98.3 \% \\
\end{array}$ & $\begin{array}{c}158 / 158 \\
100 \% \\
\end{array}$ \\
\hline Ethnicity & $\begin{array}{c}472 / 489 \\
96.5 \% \\
\end{array}$ & $\begin{array}{c}471 / 476 \\
98.9 \%\end{array}$ & $\begin{array}{c}208 / 208 \\
100 \% \\
\end{array}$ \\
\hline Aware of Lifeline & $\begin{array}{c}488 \text { / } 489 \\
99.8 \% \\
\end{array}$ & $\begin{array}{c}475 \text { / } 476 \\
99.8 \% \\
\end{array}$ & $\begin{array}{c}208 / 208 \\
100 \% \\
\end{array}$ \\
\hline Subscribes to Lifeline & $\begin{array}{c}481 / 489 \\
98.4 \% \\
\end{array}$ & $\begin{array}{c}471 / 476 \\
98.9 \% \\
\end{array}$ & $\begin{array}{c}207 / 208 \\
99.5 \% \\
\end{array}$ \\
\hline Would Sign Up If Eligible & $\begin{array}{c}431 / 479 \\
90.0 \%\end{array}$ & $\begin{array}{c}436 / 466 \\
93.6 \%\end{array}$ & $\begin{array}{c}206 / 207 \\
99.5 \% \\
\end{array}$ \\
\hline
\end{tabular}




\section{Appendix B: Income Guidelines for Lifeline Eligibility}

Low-income households qualify for Lifeline either by proving eligibility for a qualified federal program or by proving eligibility by having an annual household income less than 135 percent of the FPG. Table B1 lists the current eligibility guidelines based on the income criterion for Lifeline eligibility using US FPG guidelines for the year 2008.

Table B1

Maximum Household Income for Lifeline Eligibility in 2008

\begin{tabular}{|c|c|}
\hline Household Size & 135\% of FPG (Maximum Income) \\
\hline 1 & $\$ 14,040$ \\
\hline 2 & $\$ 18,900$ \\
\hline 3 & $\$ 23,760$ \\
\hline 4 & $\$ 28,620$ \\
\hline 5 & $\$ 33,480$ \\
\hline 6 & $\$ 38,340$ \\
\hline 7 & $\$ 43,200$ \\
\hline 8 & $\$ 48,060$ \\
\hline 9 & $\$ 52,920$ \\
\hline 10 & $\$ 57,780$ \\
\hline
\end{tabular}

As noted in Section IV, the survey did not ask respondents to report an exact household income amount; instead, it asked respondents to indicate a range in which their income falls. The advantage of using this approach is that it increases the likelihood of a truthful response to a question that some may consider too private to answer. We use increments of $\$ 10,000$ in order to reduce the potential variations in incomes within each range. One drawback of using income ranges is the inability to exactly determine whether a respondent is eligible for Lifeline based on his or her reported income range and household size. For example, a respondent who reports a household size of three and an income range of $\$ 20,000$ to $\$ 29,999$ is eligible for Lifeline if his 
income is between $\$ 20,000$ and $\$ 23,760$, and is not eligible for Lifeline if his income is between $\$ 23,760$ and $\$ 29,999$. Because we do not know the respondent's exact income, we use the midpoint of the income range, $\$ 25,000$, to determine presumed eligibility. In this case, the respondent would be presumed non-eligible for Lifeline since $\$ 25,000$ is greater than the maximum income of $\$ 23,760$. However, if the respondent had reported a household size of four and an income range of $\$ 20,000$ to $\$ 29,999$, this respondent would be presumed eligible for Lifeline since $\$ 25,000$ (the midpoint of the reported income range) is less than the maximum income for a household of four, $\$ 28,620$.

Using this approach, we show the parameters for determining presumed eligibility on page 20. Comparing these parameters with those in Table B1, we can determine the probability of an incorrect eligibility designation, assuming that actual incomes are evenly distributed across each income range. For example, for a household of one with reported income of less than $\$ 10,000$, the probability of an error is $0 \%$. In fact, for the majority of respondents in each survey, the probability of an error is $0 \%$ since all incomes within that income range are considered either eligible or non-eligible. For example, all household sizes of one or two with household income greater than $\$ 20,000$ are non-eligible for Lifeline, while all households of five or more with household income less than $\$ 30,000$ are eligible for Lifeline. Only for the combinations of household size and income ranges in which an actual Lifeline income cutoff occurs (e.g., for household sizes of three or four with household income of $\$ 20,000$ to $\$ 29,999$ ) does a probability of an incorrect designation exist. This applies to only $10.1 \%, 11.1 \%$, and $16.7 \%$ of total respondents in the landline, cellular, and intercept surveys, respectively. For example, for a household of four with reported income of $\$ 20,000$ to $\$ 29,999$ (which we presume as eligible), the probability of an error (that actual household income is greater than $\$ 28,620$ ) is $14 \%$. 
Because the occurrence of these errors affect a relatively small proportion of total respondents, our procedure of classifying respondents as presumed eligible or presumed non-eligible based on reported household sizes and income ranges should not create significant concern. 


\section{Appendix C: Empirical Estimation and Results}

To address our primary empirical questions, we employ maximum-likelihood probit models, pairwise correlation tests, and one-sample and two-sample mean comparison tests. A brief explanation of these models follows. The probit model predicts the probability of the dependent variable given the independent variables we expect to influence the outcome. This model is appropriate given our dichotomous dependent variables of choice: awareness of Lifeline, subscription to Lifeline, owning a cellular phone, and owning a landline phone. In the probit models, we report the marginal effect of a change in the probability of the dependent variable for an infinitesimal change in each independent, continuous variable and for a discrete change in the probability for dummy variables evaluated at the mean. The first model is given by $\operatorname{Pr}($ dependent variable $=1)=\beta_{0}+\beta_{1} X+\varepsilon$, where $X_{i}$ represents the matrix of independent variables associated with each respondent and $\varepsilon$ is a normally distributed error term. With our survey data, we observe the outcome directly; therefore, we are able to directly estimate coefficients on variables deemed likely to drive the dependent variables.

Within each estimation, we include explanatory variables in two primary categories: telephone value and usage related variables, and those describing demographic and socioeconomic characteristics. Specifically, we include whether a respondent owns a cellular phone (Own Cell), the percentage of total phone calls the respondent makes with a cellular phone (Percent Total Calls with Cell), and the value the respondent places on both his cellular phone and his landline phone (Cell Worth and Landline Worth).

Socioeconomic characteristics are captured through the respondent's age (Age), education level (Education), gender, and ethnicity (Male, White, Black, and Hispanic with an excluded category for all other races and ethnicities), type of home the respondent lives in (Own Home and 
Residence Type), and the number of people living in the respondent's household (Household Number). Finally, we include the respondent's reported annual income (Household Income) and alternately incorporate our variable developed from respondent's reported income and household number (Eligible). Other characteristics were estimated in addition to those reported; however, specifications were less robust and such variables were not statistically significant in any iteration. Our estimates are generated separately for data obtained from the landline survey, the cellular survey, and the intercept survey. Table $\mathrm{C} 1$ provides summary statistics for those variables included in the models.

While our models produced some statistically significant results, we were unable to design a strong model that produced any significant results in large measure. Consequently, we attempted to provide statistically significant results of specific questions posed throughout the paper. In practice, this means we performed tests on the equality of means of variables in question and segregated the data by survey method, landline and cellular ownership, and household income in order to provide statistically valid results to support our assertions. Details of all the tests used and results are available from the authors upon request. 
Table C1

Summary Statistics of Variables Used in Empirical Analysis, 2008

\begin{tabular}{|c|c|c|c|c|c|c|c|c|c|c|c|c|}
\hline \multirow{2}{*}{ Variable } & \multicolumn{4}{|c|}{ Landline Survey } & \multicolumn{4}{|c|}{ Cellular Survey } & \multicolumn{4}{|c|}{ Intercept Survey } \\
\hline & Obs. & Mean & Min & Max & Obs. & Mean & Min & Max & Obs. & Mean & Min & Max \\
\hline Subscribe to Lifeline ( $1=$ yes $)$ & 481 & $\begin{array}{r}0.017 \\
(0.128) \\
\end{array}$ & 0 & 1 & 471 & $\begin{array}{r}0.021 \\
(0.144) \\
\end{array}$ & 0 & 1 & 181 & $\begin{array}{r}0.066 \\
(0.249) \\
\end{array}$ & 0 & 1 \\
\hline Aware of Lifeline ( 1 = yes) & 489 & $\begin{array}{r}0.182 \\
(0.578)\end{array}$ & 0 & 1 & 476 & $\begin{array}{r}0.158 \\
(0.568)\end{array}$ & 0 & 1 & 182 & $\begin{array}{r}0.434 \\
(0.497)\end{array}$ & 0 & 1 \\
\hline Age (in years) & 488 & $\begin{array}{r}51.625 \\
(20.472)\end{array}$ & 0 & 98 & 473 & $\begin{array}{r}40.129 \\
(16.863)\end{array}$ & 0 & 99 & 206 & $\begin{array}{r}35.5 \\
(12.917) \\
\end{array}$ & 18 & 74 \\
\hline Landline Worth (\$) & 377 & $\begin{array}{r}74.528 \\
(155.337)\end{array}$ & 0 & 1,000 & 226 & $\begin{array}{r}63.863 \\
(109.563)\end{array}$ & 0 & 1,000 & 154 & $\begin{array}{r}85.143 \\
(173.257)\end{array}$ & 0 & 1,000 \\
\hline Own Cell $(1=$ yes $)$ & 487 & $\begin{array}{r}0.836 \\
(0.371)\end{array}$ & 0 & 1 & 476 & $\begin{array}{r}1.000 \\
(0.000)\end{array}$ & 1 & 1 & 205 & $\begin{array}{r}0.771 \\
(0.421)\end{array}$ & 0 & 1 \\
\hline Percent Total Calls with Cell & 370 & $\begin{array}{r}49.230 \\
(33.093) \\
\end{array}$ & 0 & 100 & 445 & $\begin{array}{r}71.960 \\
(30.260) \\
\end{array}$ & 0 & 100 & 151 & $\begin{array}{r}65.457 \\
(33.506) \\
\end{array}$ & 0 & 100 \\
\hline Cell Worth (\$) & 332 & $\begin{array}{r}104.907 \\
(177.030)\end{array}$ & 0 & 1,000 & 419 & $\begin{array}{r}127.339 \\
(195.330)\end{array}$ & 0 & 1,000 & 152 & $\begin{array}{r}129.224 \\
(235.419)\end{array}$ & 0 & 1,000 \\
\hline Residence Type* & 486 & $\begin{array}{r}3.644 \\
(0.994)\end{array}$ & 1 & 5 & 476 & $\begin{array}{r}3.359 \\
(1.286)\end{array}$ & 1 & 5 & 208 & $\begin{array}{r}3.212 \\
(1.482)\end{array}$ & 1 & 5 \\
\hline Own Home $(1=$ yes $)$ & 475 & $\begin{array}{r}0.853 \\
(0.355) \\
\end{array}$ & 0 & 1 & 469 & $\begin{array}{r}0.571 \\
(0.495) \\
\end{array}$ & 0 & 1 & 202 & $\begin{array}{r}0.193 \\
(0.396) \\
\end{array}$ & 0 & 1 \\
\hline Household Number & 477 & $\begin{array}{r}2.583 \\
(1.363)\end{array}$ & 1 & 8 & 475 & $\begin{array}{r}3.221 \\
(1.996)\end{array}$ & 1 & 20 & 207 & $\begin{array}{r}3.430 \\
(1.747)\end{array}$ & 1 & 12 \\
\hline Black (1 = yes $)$ & 489 & $\begin{array}{r}0.074 \\
(0.261)\end{array}$ & 0 & 1 & 476 & $\begin{array}{r}0.166 \\
(0.372)\end{array}$ & 0 & 1 & 208 & $\begin{array}{r}0.452 \\
(0.499)\end{array}$ & 0 & 1 \\
\hline White (1 = yes) & 489 & $\begin{array}{r}0.773 \\
(0.419) \\
\end{array}$ & 0 & 1 & 476 & $\begin{array}{r}0.597 \\
(0.491) \\
\end{array}$ & 0 & 1 & 208 & $\begin{array}{r}0.279 \\
(0.450) \\
\end{array}$ & 0 & 1 \\
\hline Hispanic $(1=$ yes $)$ & 489 & $\begin{array}{r}0.102 \\
(0.303)\end{array}$ & 0 & 1 & 476 & $\begin{array}{r}0.204 \\
(0.403)\end{array}$ & 0 & 1 & 208 & $\begin{array}{r}0.202 \\
(0.402)\end{array}$ & 0 & 1 \\
\hline Male $(1=$ yes $)$ & 489 & $\begin{array}{r}0.364 \\
(0.645)\end{array}$ & 0 & 1 & 476 & $\begin{array}{r}0.500 \\
(0.501)\end{array}$ & 0 & 1 & 208 & $\begin{array}{r}0.173 \\
(0.379)\end{array}$ & 0 & 1 \\
\hline Education** & 481 & $\begin{array}{r}4.331 \\
(1.192) \\
\end{array}$ & 1 & 6 & 464 & $\begin{array}{r}4.039 \\
(1.209) \\
\end{array}$ & 1 & 6 & 208 & $\begin{array}{r}3.332 \\
(1.138) \\
\end{array}$ & 1 & 6 \\
\hline
\end{tabular}




\begin{tabular}{|c|c|c|c|c|c|c|c|c|c|c|c|c|}
\hline \multirow{2}{*}{ Variable } & \multicolumn{4}{|c|}{ Landline Survey } & \multicolumn{4}{|c|}{ Cellular Survey } & \multicolumn{4}{|c|}{ Intercept Survey } \\
\hline & Obs. & Mean & Min & Max & Obs. & Mean & Min & Max & Obs. & Mean & Min & Max \\
\hline Household Income*** & 357 & $\begin{array}{r}5.796 \\
(2.613)\end{array}$ & 1 & 10 & 398 & $\begin{array}{r}5.201 \\
(2.746)\end{array}$ & 1 & 10 & 195 & $\begin{array}{r}2.179 \\
(1.430)\end{array}$ & 1 & 8 \\
\hline Eligible $(1=$ yes $)$ & 357 & $\begin{array}{r}0.140 \\
(0.348)\end{array}$ & 0 & 1 & 398 & $\begin{array}{r}0.251 \\
(0.434)\end{array}$ & 0 & 1 & 204 & $\begin{array}{r}0.917 \\
(0.277)\end{array}$ & 0 & 1 \\
\hline
\end{tabular}

$*$ Apartment $=1 ;$ Condo $=2 ;$ Townhouse $=3 ;$ House $=4 ;$ Other $=5$.

** Less than High School = 1; Some High School = 2; High School Graduate = 3; Some College = 4; College Graduate = 5; Post-Graduate =6

$* * *$ Less than $\$ 10,000=1 ; \$ 10,000$ to $\$ 19,999=2 ; \$ 20,000$ to $\$ 29,999=3 ; \$ 30,000$ to $\$ 39,999=4 ; \$ 40,000$ to $\$ 49,999=5 ; \$ 50,000$ to $\$ 59,999$ $=6 ; \$ 60,000$ to $\$ 79,999=7 ; \$ 80,000$ to $\$ 99,999=8 ; \$ 100,000$ to $\$ 150,000=9$; over $\$ 150,000=10$. 